\title{
Article \\ Effect of Oversulfation on the Composition, Structure, and In Vitro Anti-Lung Cancer Activity of Fucoidans Extracted from Sargassum aquifolium
}

\author{
Hui-Hua Hsiao ${ }^{1,2,3,4,5}$, Tien-Chiu Wu ${ }^{4,5}$, Yung-Hsiang Tsai ${ }^{6}$, Chia-Hung Kuo ${ }^{6} \oplus$, Ren-Han Huang ${ }^{7}$, \\ Yong-Han Hong ${ }^{8, *}$ and Chun-Yung Huang ${ }^{6, *(\mathbb{D}}$
}

check for

updates

Citation: Hsiao, H.-H.; Wu, T.-C.; Tsai, Y.-H.; Kuo, C.-H.; Huang, R.-H.; Hong, Y.-H.; Huang, C.-Y. Effect of Oversulfation on the Composition, Structure, and In Vitro Anti-Lung Cancer Activity of Fucoidans Extracted from Sargassum aquifolium. Mar. Drugs 2021, 19, 215. https:// doi.org/10.3390/md19040215

Academic Editor: Roland Ulber

Received: 14 March 2021

Accepted: 8 April 2021

Published: 12 April 2021

Publisher's Note: MDPI stays neutral with regard to jurisdictional claims in published maps and institutional affiliations.

Copyright: (C) 2021 by the authors. Licensee MDPI, Basel, Switzerland. This article is an open access article distributed under the terms and conditions of the Creative Commons Attribution (CC BY) license (https:// creativecommons.org/licenses/by/ $4.0 /)$.
1 Faculty of Medicine, Kaohsiung Medical University, Kaohsiung 80708, Taiwan; huhuhs@kmu.edu.tw 2 Center for Cancer Research, Kaohsiung Medical University, Kaohsiung 80708, Taiwan

3 Center for Liquid Biopsy and Cohort Research, Kaohsiung Medical University, Kaohsiung 80708, Taiwan

4 Division of Hematology and Oncology, Department of Internal Medicine, Kaohsiung Medical University Hospital, Kaohsiung Medical University, Kaohsiung 80756, Taiwan; 960552@ms.kmuh.org.tw

5 Cancer Center, Kaohsiung Medical University Hospital, Kaohsiung Medical University, Kaohsiung 80756, Taiwan

6 Department of Seafood Science, National Kaohsiung University of Science and Technology, No. 142, Haijhuan Rd., Nanzih District, Kaohsiung City 81157, Taiwan; yht@nkust.edu.tw (Y.-H.T.); kuoch@nkust.edu.tw (C.-H.K.)

7 Mackay Memorial Hospital Emergency Department, No. 92, Sec. 2, Zhongshan North Rd., Taipei City 10449, Taiwan; lisa68850@gmail.com

8 Department of Nutrition, Yanchao Campus, I-Shou University, No. 8, Yida Rd., Jiaosu Village, Yanchao District, Kaohsiung City 82445, Taiwan

* Correspondence: yonghan@isu.edu.tw (Y.-H.H.); cyhuang@nkust.edu.tw (C.-Y.H.); Tel.: +886-7-6151100 (ext. 7914) (Y.-H.H.); +886-7-3617141 (ext. 23606) (C.-Y.H.)

Abstract: Intensive efforts have been undertaken in the fields of prevention, diagnosis, and therapy of lung cancer. Fucoidans exhibit a wide range of biological activities, which are dependent on the degree of sulfation, sulfation pattern, glycosidic branches, and molecular weight of fucoidan. The determination of oversulfation of fucoidan and its effect on anti-lung cancer activity and related signaling cascades is challenging. In this investigation, we used a previously developed fucoidan (SCA), which served as a native fucoidan, to generate two oversulfated fucoidan derivatives (SCAS1 and SCA-S2). SCA, SCA-S1, and SCA-S2 showed differences in compositions and had the characteristic structural features of fucoidan by Fourier transform infrared (FTIR) and nuclear magnetic resonance (NMR) analyses. The anticancer properties of SCA, SCA-S1, and SCA-S2 against human lung carcinoma A-549 cells were analyzed in terms of cytotoxicity, cell cycle, Bcl-2 expression, mitochondrial membrane potential (MMP), expression of caspase-3, cytochrome $c$ release, Annexin $\mathrm{V} /$ propidium iodide (PI) staining, DNA fragmentation, and the underlying signaling cascades. Our findings indicate that the oversulfation of fucoidan promotes apoptosis of lung cancer cells and the mechanism may involve the Akt/mTOR/S6 pathway. Further in vivo research is needed to establish the precise mechanism whereby oversulfated fucoidan mitigates the progression of lung cancer.

Keywords: anti-lung cancer; apoptosis; brown algae; fucoidan; human lung carcinoma A-549 cells; oversulfation; Sargassum aquifolium

\section{Introduction}

Lung cancer is the most common cancer worldwide and has high morbidity and mortality rates. Thus, considerable research efforts have been undertaken aimed at improving the prevention, diagnosis, and treatment of this disease [1]. The biggest risk factors for lung cancer are habitual smoking of tobacco, air pollution (indoor and outdoor), radiation, and occupational exposure to hazardous chemicals [2]. Lung cancer is the most prevalent form of cancer in Taiwan and is the most common cause of cancer-related mortality [3]. 
While therapeutic approaches for lung cancer have seen significant advances in recent years, the treatment of this disease remains a considerable clinical challenge. Hence, in order to improve patient outcomes, there is a crucial need for novel agents and targets for the treatment of lung cancer.

Fucoidan has been shown to exhibit impressive biological activities, such as antioxidant, immunoregulatory, anti-inflammatory, antitumor, and antithrombotic effects [4]. The degree of sulfation, sulfation pattern, molecular weight (MW), and glycosidic branches of various fucoidans influence the aforementioned biological activities [4]. Sulfate content appears to be the most critical variable [5]. According to a study conducted by Soeda et al. [5], fucoidan derivatives with varying sulfate contents were capable of promoting tissue plasminogen activator (t-PA)-induced plasma clot lysis and preventing the formation of fibrin polymers. These activities were enhanced in direct proportion to the degree of sulfation. In another study by Koyanagi et al. [6], it was shown that oversulfated fucoidans demonstrated greater anti-angiogenic activity compared with native fucoidans, and therefore they were able to inhibit the growth of tumor cells more effectively by suppressing angiogenesis. Moreover, in comparison with native fucoidans, oversulfated fucoidans appeared to show more potent anticancer activity against AGS, a human stomach cancer cell line [7]. The above-mentioned studies indicate that the sulfate content of fucoidans has a significant influence on their biological properties and that the modification of sulfate content could thus potentially enhance said properties. A number of studies have explored the biological activities of oversulfated fucoidans, but relatively little is known about the effects that varying levels of sulfation of fucoidan have on anti-lung cancer activity, and the mechanism involved remains poorly understood.

This investigation is an extension of our previous study, in which a native fucoidan (SC) was created from single-screw extrusion pretreated Sargassum aquifolium. Three degraded fucoidan products were developed: SCA (degradation of SC by ascorbic acid), SCH (degradation of SC by hydrogen peroxide), and SCAH (degradation of SC by ascorbic acid + hydrogen peroxide). The results of the study showed that SCA had high cytotoxicity to lung cancer cells as well as a strong ability to suppress Bcl-2 expression in lung cancer cells. Moreover, SCA showed high efficacy with respect to induction of cytochrome $c$ release, promotion of late apoptosis of lung cancer cells, and activation of caspase-9 and -3 [8]. In the present study, SCA served as a native fucoidan from which two fucoidan derivatives with different levels of sulfation were generated: SCA-S1 and SCA-S2. Then we analyzed the anticancer activities of SCA, SCA-S1, and SCA-S2 against human lung carcinoma A-549 cells in terms of cell cycle, cytotoxicity, expression of caspase-3, mitochondrial membrane potential (MMP), cytochrome $c$ release, Bcl-2 expression, Annexin V/ propidium iodide (PI) staining, and DNA fragmentation, as well as the underlying signaling transduction cascades. To the best of the authors' knowledge, this is the first study to investigate a potential mechanism of anti-lung cancer activity involving oversulfated fucoidans obtained from single-screw extrusion pretreated S. aquifolium. In future research, we intend to explore the clinical applications of oversulfated fucoidans in the treatment and prevention of lung cancer and possibly other cancers.

\section{Results}

\subsection{Preparation of Oversulfated Fucoidans (SCA-S1 and SCA-S2) and Compositional Analysis}

SCA is a degraded fucoidan product, which was previously produced by our laboratory. The results of our in vitro analyses demonstrated that SCA possesses anti-lung cancer properties [8]. We used SCA in the present study as a native fucoidan and created two oversulfated fucoidans termed SCA-S1 and SCA-S2. Table 1 displays the chemical and monosaccharide compositions of SCA, SCA-S1, and SCA-S2. The percentages of sulfate content for SCA, SCA-S1, and SCA-S2 were $13.67 \pm 2.19 \%, 34.67 \pm 3.73 \%$, and $60.63 \pm 3.69 \%$, respectively. The greater sulfate content in SCA-S1 and SCA-S2 indicates that the addition of sulfate in SCA was successful. The total sugar contents of SCA, SCA-S1, and SCA-S2 ranged from $28.95 \pm 0.24 \%$ to $41.70 \pm 0.91 \%$ ( $w / w$, dry basis). The addition of 
sulfate to fucoidan generally resulted in a reduction in total sugar content. The fucose contents of SCA, SCA-S1, and SCA-S2 were $35.22 \pm 2.79 \%, 20.36 \pm 1.52 \%$, and $12.58 \pm 0.46 \%$, respectively. Similarly, the fucose content of fucoidan was found to be lower following oversulfation. These results suggest that the addition of sulfate to fucoidan lowers its total sugar and fucose contents. Table 1 shows the monosaccharide compositions of these fucoidans. The major neutral sugar constituents in SCA were galactose, fucose, and galacturonic acid, while the minor sugar units consisted of xylose, mannose, and glucuronic acid. The monosaccharide composition of fucoidan did not appear to change significantly following oversulfation, although SCA-S1 and SCA-S2 showed a reduction in galacturonic acid. Taken together, the aforementioned results indicate that oversulfated fucoidans had higher sulfate content, lower total sugar and fucose contents, and monosaccharide compositions were altered, albeit only slightly. Our results demonstrated differences in compositions among SCA, SCA-S1, and SCA-S2, and thus further analyses of the biological functions of these fucoidans are warranted.

Table 1. Compositional analysis of SCA, SCA-S1, and SCA-S2.

\begin{tabular}{|c|c|c|c|}
\hline Chemical Composition & $\mathrm{SCA}^{2}$ & SCA-S1 $^{2}$ & SCA-S2 $^{2}$ \\
\hline Sulfate (\%) ${ }^{1}$ & $13.67 \pm 2.19^{a}$ & $34.67 \pm 3.73^{b}$ & $60.63 \pm 3.69^{c}$ \\
\hline Total sugar $(\%)^{1}$ & $41.70 \pm 0.91^{\mathrm{c}}$ & $28.95 \pm 0.24^{\mathrm{a}}$ & $35.08 \pm 0.21^{b}$ \\
\hline Fucose $(\%)^{1}$ & $35.22 \pm 2.79^{c}$ & $20.36 \pm 1.52^{b}$ & $12.58 \pm 0.46^{\mathrm{a}}$ \\
\hline $\begin{array}{c}\text { Monosaccharide Composition } \\
\text { (Molar Ratio) }\end{array}$ & SCA & SCA-S1 & SCA-S2 \\
\hline Fucose & 1 & 1 & 1 \\
\hline Galactose & 0.30 & 0.28 & 0.27 \\
\hline Glucuronic acid & 0.01 & $\mathrm{ND}^{3}$ & ND \\
\hline Galacturonic acid & 0.11 & ND & ND \\
\hline Mannose & 0.05 & 0.05 & 0.05 \\
\hline Xylose & 0.05 & ND & 0.04 \\
\hline
\end{tabular}

${ }^{1}$ Total sugars (\%), fucose $(\%)$, and sulfate $(\%)=(g / g$, dry basis $) \times 100 ;{ }^{2}$ Experiments were performed in triplicate; values in the same row with varying letters differ $(p<0.05) ;{ }^{3} \mathrm{ND}$ : not detected.

\subsection{Structural Analysis of SCA, SCA-S1, and SCA-S2}

Fourier transform infrared (FTIR) and nuclear magnetic resonance (NMR) techniques were employed to conduct structural analyses of SCA, SCA-S1, and SCA-S2. Figure 1 depicts IR bands at 3401 and $2940 \mathrm{~cm}^{-1}$ which correspond to the presence of $\mathrm{OH}$ and $\mathrm{H}_{2} \mathrm{O}$ stretching vibration and $\mathrm{C}-\mathrm{H}$ stretching of the pyranoid ring or the C-6 group of fucose and galactose units $[9,10]$. Absorption bands were detected at 1621 and $1421 \mathrm{~cm}^{-1}$ which can be attributed to the scissoring vibration of $\mathrm{H}_{2} \mathrm{O}$ and in-plane ring $\mathrm{CCH}, \mathrm{COH}$, and $\mathrm{OCH}$ vibrations, characteristic of the absorption pattern of polysaccharide [9-11]. The peaks at 1243 and $1055 \mathrm{~cm}^{-1}$ can be ascribed to the presence of the asymmetric stretching of $\mathrm{S}=\mathrm{O}$ and the $\mathrm{C}-\mathrm{O}-\mathrm{C}$ stretching vibrations in ring or $\mathrm{C}-\mathrm{O}-\mathrm{H}$ in the glucosidal bond $[9,10]$. The absorption bands at 900 and $840 \mathrm{~cm}^{-1}$ were due to the presence of $\mathrm{C} 1-\mathrm{H}$ bending in the $\beta$-anomeric link of galactose and equatorial $\mathrm{C}-\mathrm{O}-\mathrm{S}$ bending vibration of sulfate substituents at the axial C-4 position [12]. The bands at 620 and $580 \mathrm{~cm}^{-1}$ may correspond to symmetric and anti-symmetric $\mathrm{O}=\mathrm{S}=\mathrm{O}$ deformations [13]. Figure 2A shows the ${ }^{1} \mathrm{H}-\mathrm{NMR}$ spectra for SCA, SCA-S1, and SCA-S2. The signals from 5.5 to $5.0 \mathrm{ppm}$ can be attributed to L-fucopyranosyl units [14]. The signal at $4.46 \mathrm{ppm}$, which was most apparent in SCA, denotes the presence of $\mathrm{H}-2$ in a 2-sulfated fucopyranose residue [14], and the signal at $4.13 \mathrm{ppm}(4[\mathrm{H}])$ indicates the presence of 3-linked $\alpha$-L-fucose [14]. Signals with a ppm of $4.07 / 3.95\left(6[\mathrm{H}] / 6^{\prime}[\mathrm{H}]\right)$, which were pronounced in SCA, can be explained by the presence of a (1-6)- $\beta$-D-linked galacton [15]. Moreover, the signals from 3.9 to $3.6 \mathrm{ppm}$ could be characteristic signals of mannitol [16,17], which is frequently extracted along with fucoidan. The signal obtained at $3.72 \mathrm{ppm}$ may denote the presence of $(4[\mathrm{H}])$ 2,3 -linked $\alpha$ - $\beta$-mannose [11], and the signal at $2.14 \mathrm{ppm}$ may indicate methyl protons in 
O-acetyls [11,18], which are frequently detected in algal polysaccharides [18]. The signals at $1.92(1[\mathrm{H}])$ and $1.23 \mathrm{ppm}(6[\mathrm{H}])$ demonstrate the existence of alkyl at a sulfonyl-attached proton and an alkane proton in two methyl groups, respectively [19]. Other signals, including 7.91, 2.87, and 2.71 ppm, were detected in SCA-S1 and SCA-S2 and these may correspond to $\mathrm{N}, \mathrm{N}$-dimethylformamide (DMF), which is a sulfation reagent utilized in the oversulfate treatment of fucoidan. The ${ }^{13} \mathrm{C}-\mathrm{NMR}$ spectra (Figure $2 \mathrm{~B}$ ) for SCA, SCA-S1, and SCA-S2 revealed that the prominent signal at $101.6 \mathrm{ppm}$ and peaks between $65-80 \mathrm{ppm}$ correspond to (1-6)- $\beta$-D-linked galacton [15]. The signal at $100.3 \mathrm{ppm}$ can be assigned to a $(1,3)$-linked $\alpha$-L-fucopyranose residue [17]. The signals at 62.0 and $66.7 \mathrm{ppm}$ signified $\beta$-D-galactopyranose residues [20]. Peaks at $19-20 \mathrm{ppm}$ revealed the presence of $O$-acetyl groups [21], which is often visible in algal polysaccharides. Additional signals can be found in SCA-S1 and SCA-S2 including 164.9, 36.8, and 31.3 ppm, which can be assigned to DMF, a sulfation reagent used for oversulfation of fucoidan [22]. In summary, the data pertaining to FTIR, ${ }^{1} \mathrm{H}$ NMR, and ${ }^{13} \mathrm{C}-\mathrm{NMR}$ indicate that SCA, SCA-S1, and SCA-S2 have the characteristic structural features of fucoidan, and that DMF signals could only be detected in SCA-S1 and SCA-S2 using NMR spectra.

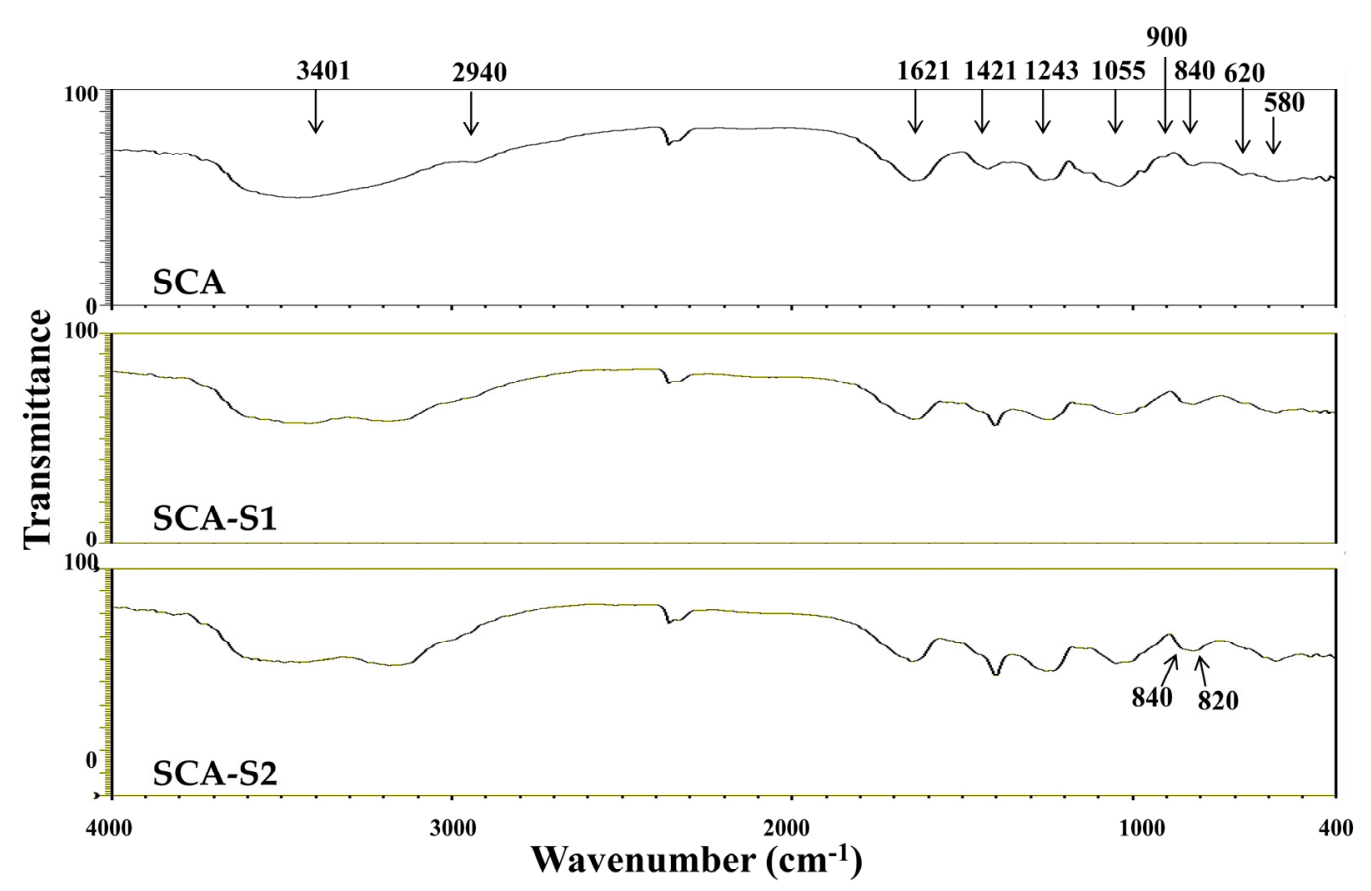

Figure 1. FTIR spectra for SCA, SCA-S1, and SCA-S2. The characteristic peaks at 3401, 2940, 1621, $1421,1243,1055,900,840,820,620$, and $580 \mathrm{~cm}^{-1}$ are labeled.

\subsection{SCA, SCA-S1, and SCA-S2 Exhibited Cytotoxic Effects on A-549 Cells}

The human lung carcinoma A-549 cell line is considered a useful in vitro model for investigations of the anti-lung cancer effects of fucoidans [8]. Figure 3A shows the cytotoxic effects of SCA, SCA-S1, and SCA-S2 on A-549 cells. All fucoidans, namely SCA, SCA-S1, and SCA-S2, had reduced ratios of live A-549 cells in a dose-dependent manner, and SCA-S1 exhibited more potent cytotoxic effects on A-549 cells compared with those of SCA and SCA-S2. BEAS-2B, a non-cancerous bronchial epithelial cell line, can be used to represent normal human lung cells [23]. Hence, we conducted a similar experiment using BEAS-2B cells to determine whether these fucoidans exert cytotoxic effects on normal cells. As shown in Figure 3B, the results suggest that SCA-S1 conferred the largest cytotoxicities on BEAS-2B cells, followed by SCA-S2 and SCA. This response was similar to that seen in A-549 cells. In addition, SCA, SCA-S1, and SCA-S2 showed lower cytotoxicities to BEAS2B in comparison with A-549 cells (Figure 3A,B). Moreover, SCA, SCA-S1, and SCA-S2 had survival rates of A-549 cells ranging from $25.9 \%$ to $53.8 \%$ at a concentration of 200 
$\mu \mathrm{g} / \mathrm{mL}$, and of BEAS-2B cells, survival rates ranged from $64.4 \%$ to $94.1 \%$, suggesting these fucoidans were less cytotoxic to normal cells. In our preliminary experiment, a treatment time of $48 \mathrm{~h}$ was found to be optimal for the induction of cytotoxicity in A-549 cells. As the survival rates of A- 549 cells were reduced to less than $50 \%$ (approx.) following treatment of these fucoidans, a concentration of $200 \mu \mathrm{g} / \mathrm{mL}$ and a treatment duration of $48 \mathrm{~h}$ were adopted for further in vitro anti-lung cancer experiments.

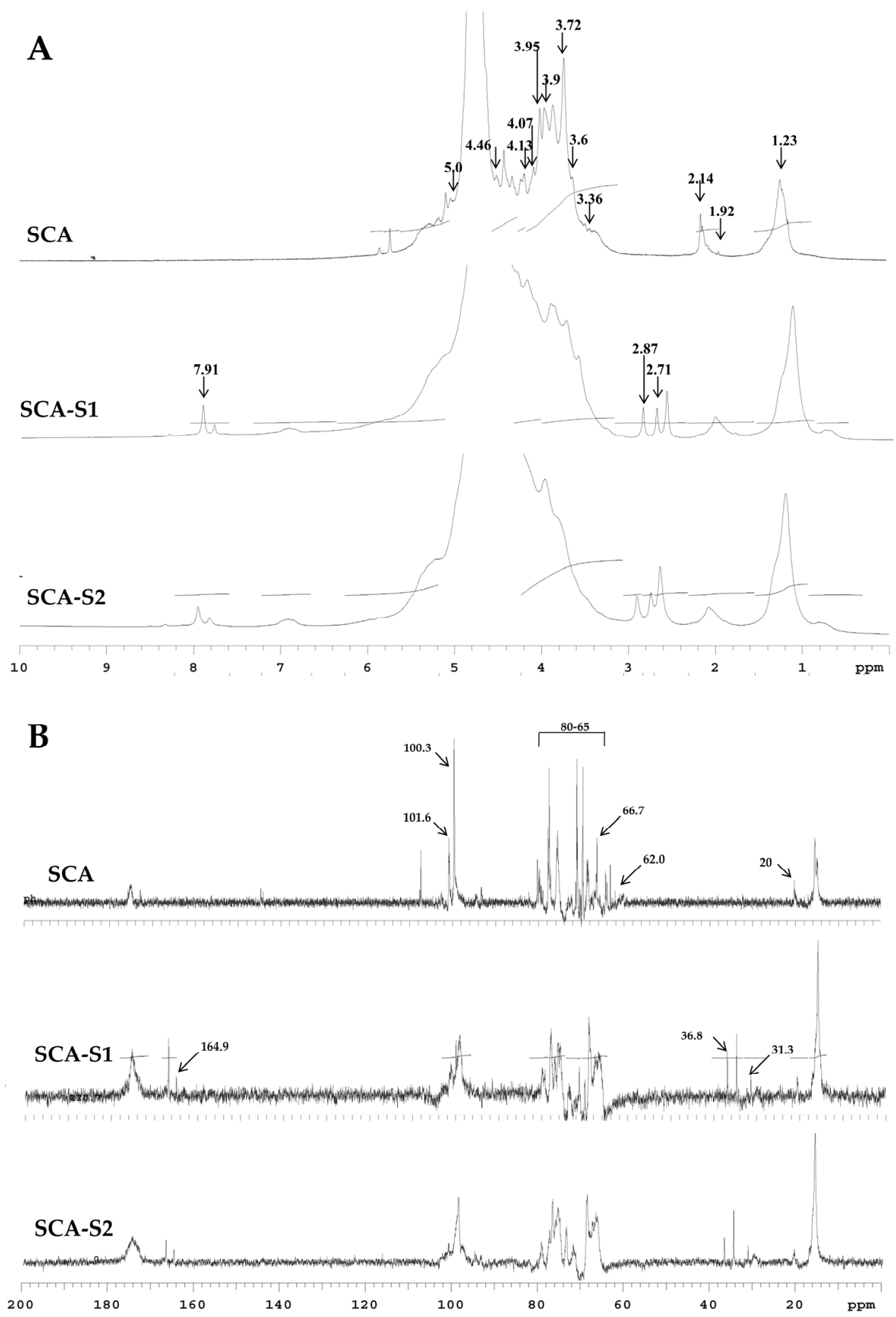

Figure 2. NMR analyses of SCA, SCA-S1, and SCA-S2. (A) ${ }^{1} \mathrm{H}-\mathrm{NMR}$ spectra for SCA, SCA-S1, and SCA-S2. The characteristic peaks at 7.91, 5.0, 4.46, 4.13, 4.07, 3.95, 3.9, 3.72, 3.6, 3.36, 2.87, 2.71, 2.14, 1.92, and $1.23 \mathrm{ppm}$ are indicated. (B) ${ }^{13} \mathrm{C}-\mathrm{NMR}$ spectra for SCA, SCA-S1, and SCA-S2. The characteristic peaks at $164.9,101.6,100.3,80-65,66.7,62.0,36.8,31.3$, and 20 ppm are indicated. 
A

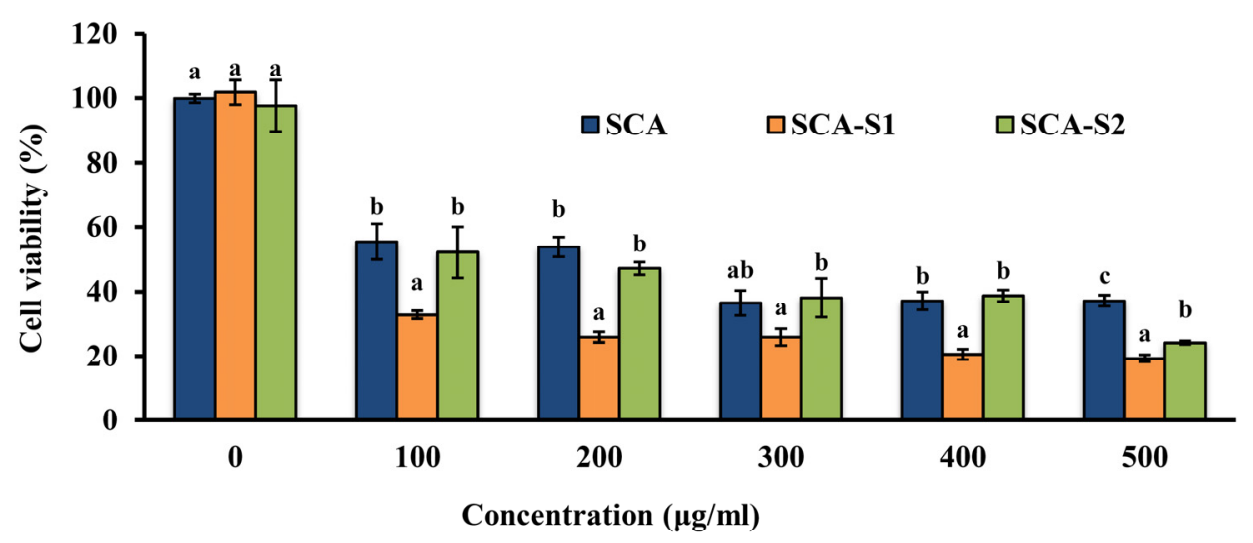

B

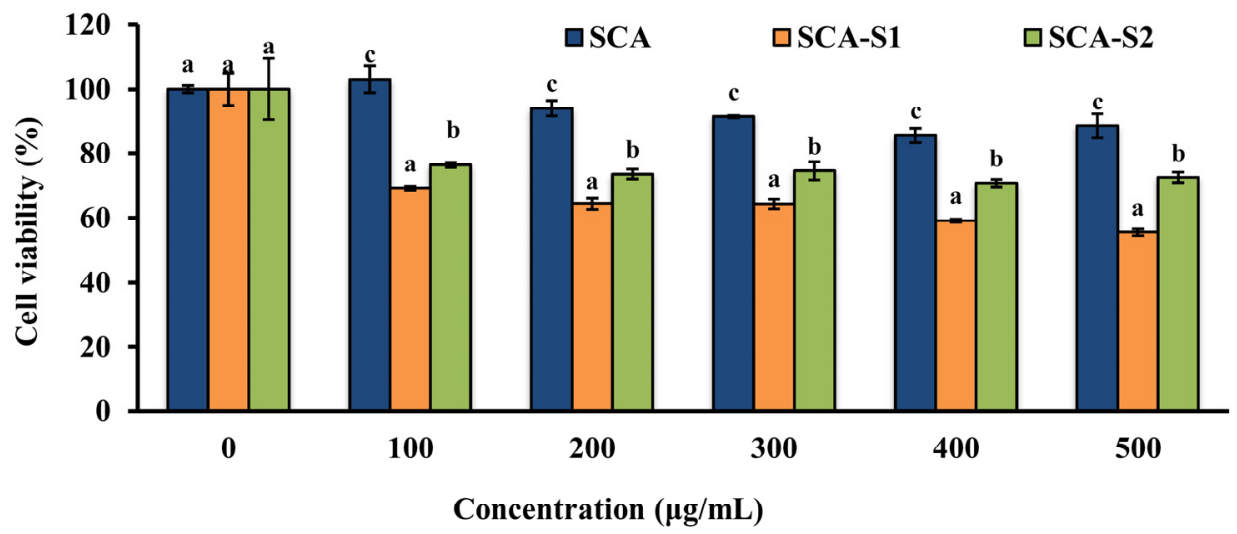

Figure 3. Effects of SCA, SCA-S1, and SCA-S2 on cell viabilities of A-549 and BEAS-2B cells: (A) A-549 cells were cotreated with $0-500 \mu \mathrm{g} / \mathrm{mL}$ of SCA, SCA-S1, and SCA-S2 for $48 \mathrm{~h}$, and the cell viability was measured by MTT assays; (B) BEAS-2B cells were coincubated with $0-500 \mu \mathrm{g} / \mathrm{mL}$ of SCA, SCA-S1, and SCA-S2 for $48 \mathrm{~h}$, and the cell viability was determined by MTT assays. Experiments were performed in triplicate. Bars with different letters significantly differ at the level of 0.05 .

\subsection{Effects of SCA, SCA-S1, and SCA-S2 on Cell Cycle Profile of A-549 Cells}

Figure 4 shows that when A-549 cells were treated with $200 \mu \mathrm{g} / \mathrm{mL}$ SCA, SCA-S1, and SCA-S2 for $48 \mathrm{~h}$, SCA-S2 had the highest percentage of cells in the sub- $G_{1}$ phase $(25.0 \pm 0.6 \%)$, followed by SCA-S1 $(13.9 \pm 0.4 \%)$, SCA $(5.33 \pm 0.12 \%)$, and untreated cells $(2.50 \pm 0.14 \%)$. The cell population in the sub- $G_{1}$ phase rose in direct proportion to the induction of DNA fragmentation [24]. As such, SCA-S2 showed the greatest DNA fragmentation (also termed sub- $G_{1}$ cell cycle arrest), followed by SCA-S1, SCA, and untreated cells. In summary, all of the tested fucoidans were capable of inducing sub- $G_{1}$ cell cycle arrest. SCA-S2 displayed the greatest ability to induce DNA fragmentation of A-549 cells.

\subsection{Effects of SCA, SCA-S1, and SCA-S2 on Mitochondrial Membrane Potential, Bcl-2 Expression, and Cytochrome c Release of A-549 Cells}

It is thought that TMRE binds to active mitochondria owing to its ability to permeate cells in addition to its positive charge. Loss of MMP is directly related to reduced TMRE binding [25]. In Figure 5, the percentage of cells with low TMRE intensity in the control was $16.7 \pm 0.4 \%$. Following treatment of A-549 cells with $200 \mu \mathrm{g} / \mathrm{mL}$ SCA, SCA-S1, and SCA-S2 for $48 \mathrm{~h}$, the percentage of cells with low TMRE intensity increased significantly to $27.3 \pm 0.4 \%, 58.2 \pm 2.0 \%$, and $65.9 \pm 0.2 \%$, respectively $(p<0.05)$, indicating the occurrence of fucoidan-induced mitochondrial dysfunction. Bcl-2 is a member of the anti-apoptotic class of B cell leukemia-2 gene product (Bcl-2) family proteins and it has been postulated that it blocks MMP depolarization [26]. In contrast, suppressed Bcl-2 expression results in cellular apoptosis. In Figure 6 it can be seen that the percentage of cells with high Bcl-2 
intensity in the control was $64.5 \pm 0.3 \%$. Treatment of A-549 cells with $200 \mu \mathrm{g} / \mathrm{mL} \mathrm{SCA}$, SCA-S1, and SCA-S2 for $48 \mathrm{~h}$ resulted in a reduction of the percentage of cells with high Bcl-2 intensity to $48.4 \pm 0.2 \%, 50.7 \pm 0.2 \%$, and $54.5 \pm 0.4 \%$, respectively, suggesting the occurrence of fucoidan-mediated suppression of Bcl-2. The release of cytochrome $c$ from mitochondria is a nearly apoptotic event and is an upstream signal of the mitochondriadependent apoptotic pathway $[27,28]$. Figure 7 shows that in the control, the percentage of cells with low cytochrome $c$ intensity was $5.07 \pm 0.26 \%$. The percentage of cells with low cytochrome $c$ intensity significantly increased to $9.57 \pm 0.21 \%, 13.2 \pm 0.1 \%$, and $16.4 \pm 0.2 \%$, respectively $(p<0.05)$, when A-549 cells were treated with $200 \mu \mathrm{g} / \mathrm{mL} \mathrm{SCA}, \mathrm{SCA}-\mathrm{S} 1$, and SCA-S2 for $48 \mathrm{~h}$, suggesting the involvement of fucoidan-mediated release of cytochrome $c$ from mitochondria. In summary, these findings indicate that SCA, SCA-S1, and SCAS2 induced mitochondria-dependent apoptotic effects, as evidenced by the loss of MMP, release of cytochrome $c$, and suppression of Bcl-2.
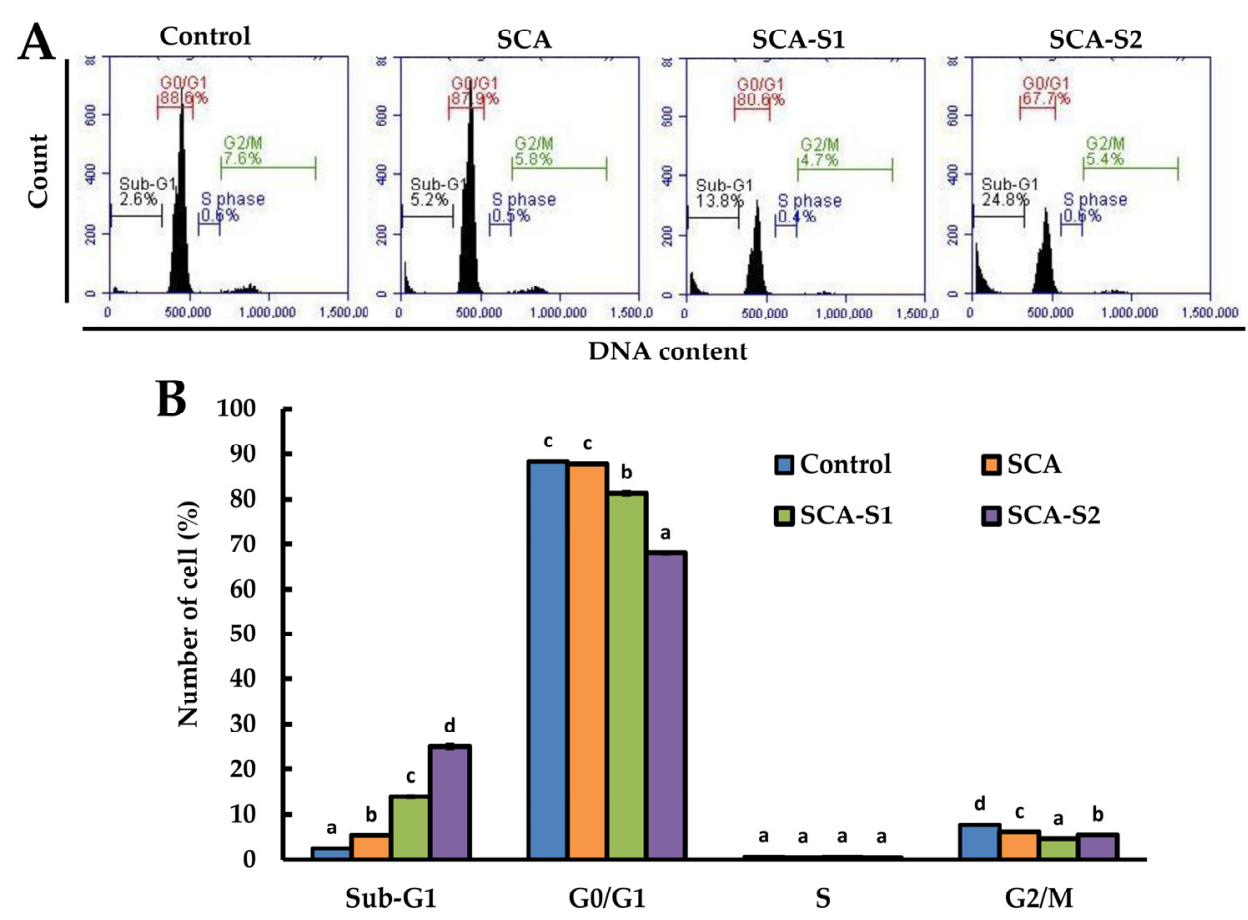

Figure 4. Effects of SCA, SCA-S1, and SCA-S2 treatments on cell cycle profiles of A-549 cells: (A) A-549 cells were treated with SCA, SCA-S1, and SCA-S2 at a concentration of $200 \mu \mathrm{g} / \mathrm{mL}$ for 48 $\mathrm{h}$, and cell cycle profiles were measured; (B) summary bar graph of three cell cytometric analyses showing the percentages of cells in the sub- $G_{1}, G_{0} / G_{1}, S$, and $G_{2} / M$ phases of the cell cycle according to treatments. Results are shown as mean \pm SD of three separate experiments. Differences exist between columns labeled with different letters at the level of 0.05 . 


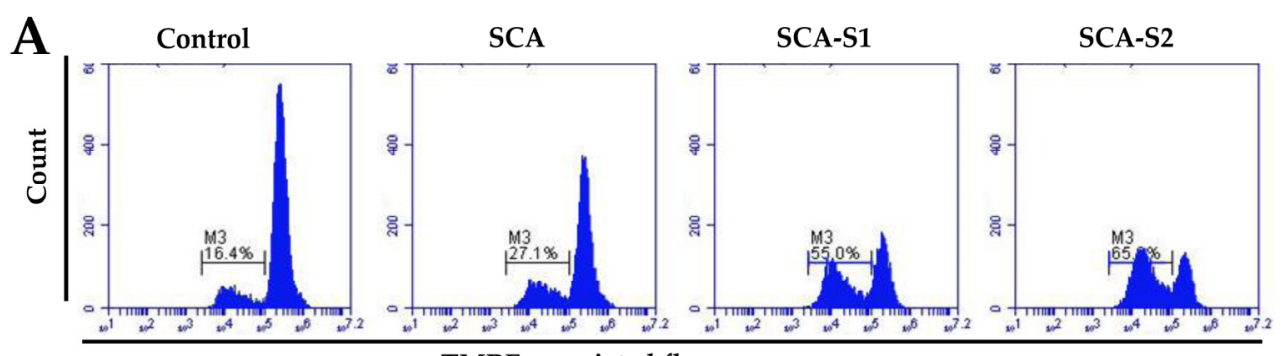

TMRE-associated fluorescence

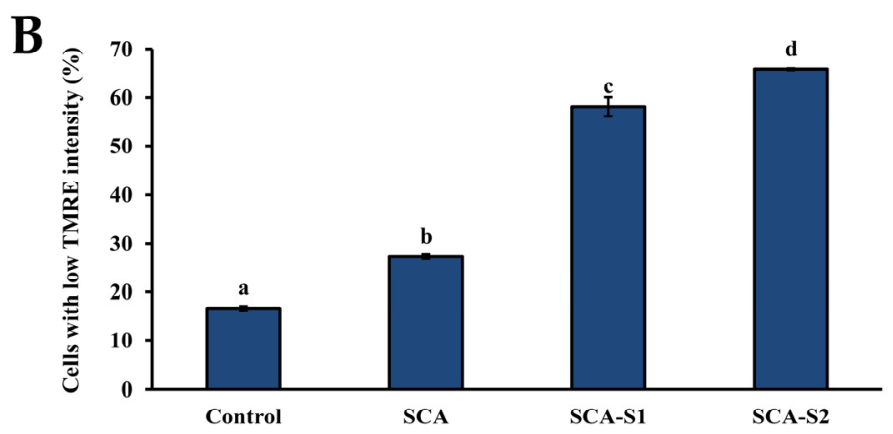

Figure 5. Effects of SCA, SCA-S1, and SCA-S2 treatments on MMP of A-549 cells. A-549 cells were treated with and without $200 \mu \mathrm{g} / \mathrm{mL}$ SCA, SCA-S1, and SCA-S2 for $48 \mathrm{~h}$, and MMP was determined by TMRE staining and flow cytometry. (A) Histograms; (B) summary bar graph of three cell cytometric analyses showing the percentages of cells with low TMRE intensity according to treatments. Results are shown as mean \pm SD of three separate experiments. Differences exist between columns labeled with different letters at the level of 0.05 .
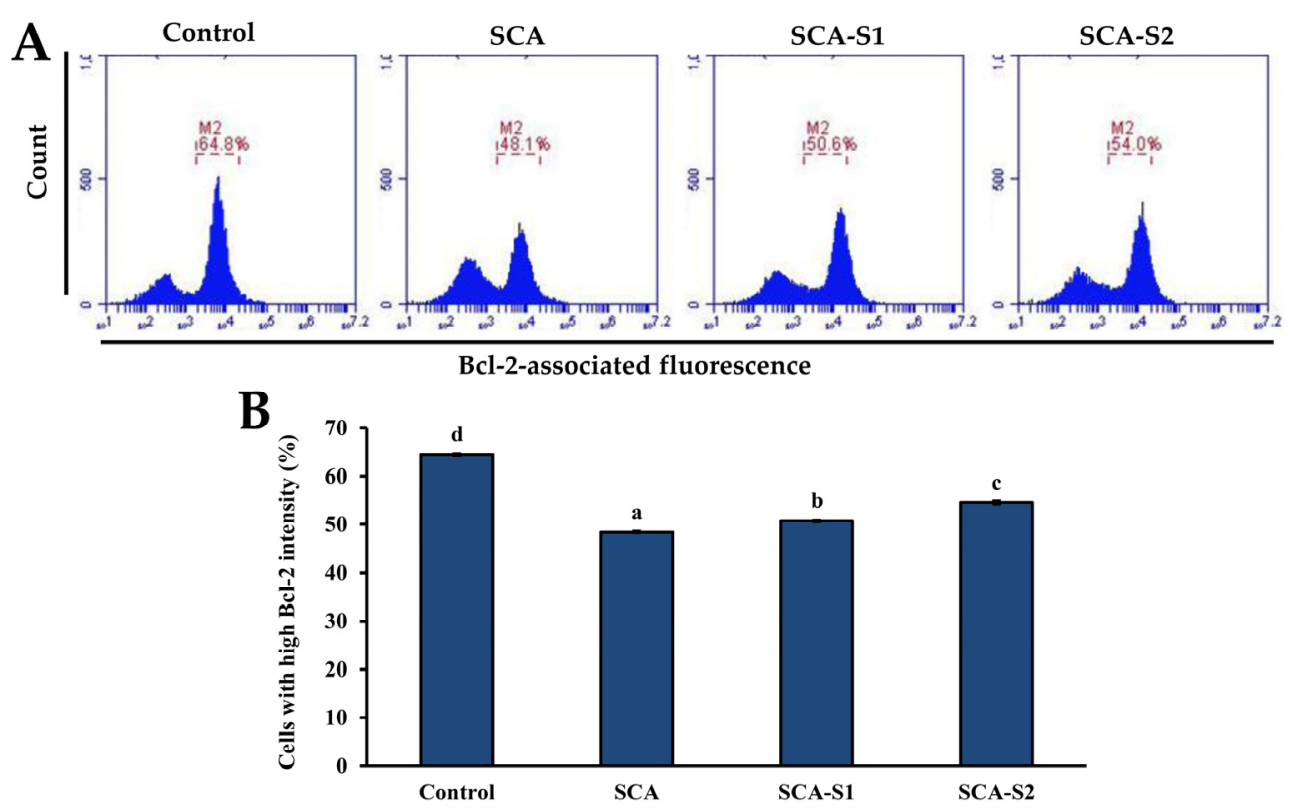

Figure 6. Effects of SCA, SCA-S1, and SCA-S2 treatments on the Bcl-2 expression in A-549 cells. A-549 cells were treated with and without $200 \mu \mathrm{g} / \mathrm{mL} \mathrm{SCA}$, SCA-S1, and SCA-S2 for $48 \mathrm{~h}$, and the level of immunolabeled Bcl-2 was determined by flow cytometry. (A) Histograms; (B) summary bar graph of three cell cytometric analyses showing the percentages of cells with high Bcl-2 intensity according to treatments. Results are shown as mean \pm SD of three separate experiments. Differences exist between columns labeled with different letters at the level of 0.05 . 

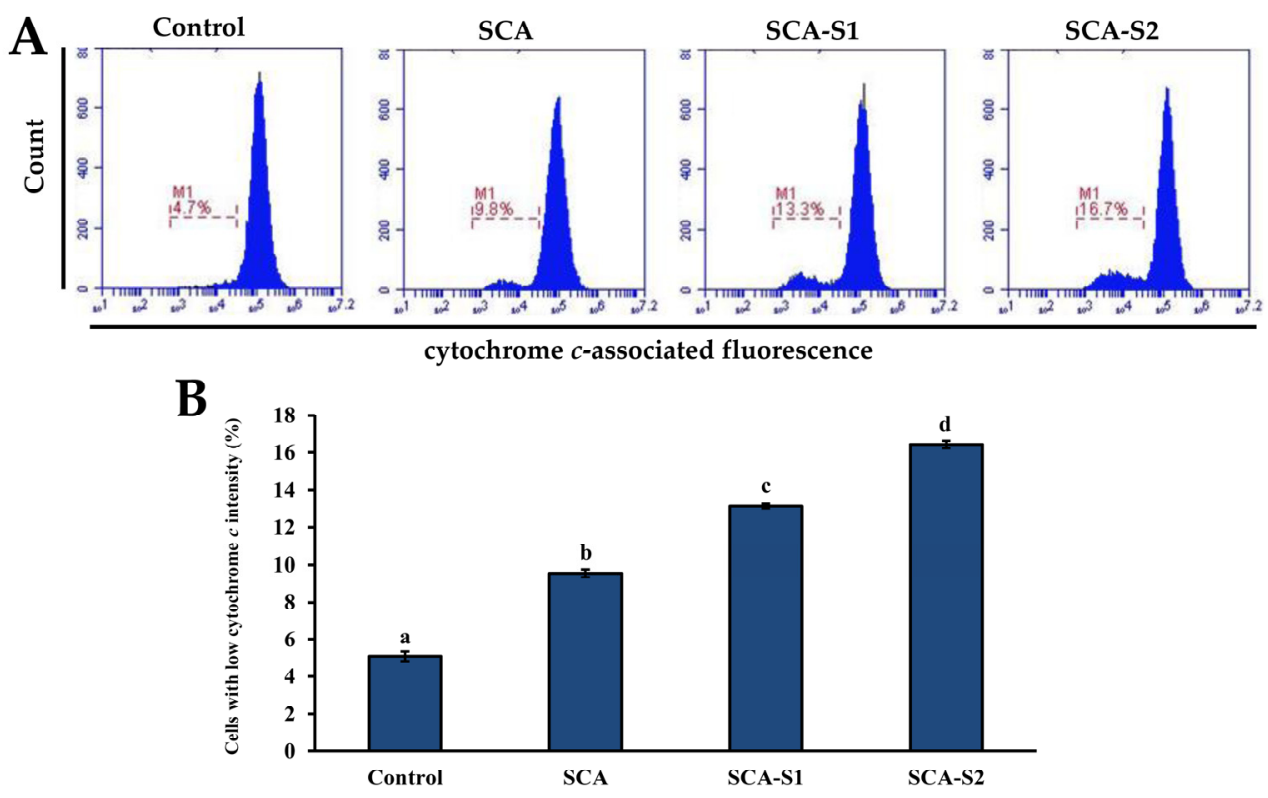

Figure 7. Effects of SCA, SCA-S1, and SCA-S2 treatments on the amount of cytochrome $c$ release in A-549 cells. A-549 cells were treated with and without $200 \mu \mathrm{g} / \mathrm{mL}$ SCA, SCA-S1, and SCA-S2 for 48 $\mathrm{h}$, and the level of immunolabeled cytochrome $c$ was determined by flow cytometry. (A) Histograms; (B) summary bar graph of three cell cytometric analyses showing the percentages of cells with low cytochrome $c$ intensity according to treatments. Results are shown as mean \pm SD of three separate experiments. Differences exist between columns labeled with different letters at the level of 0.05 .

2.6. Effects of SCA, SCA-S1, and SCA-S2 on Activation of Caspase-3 and DNA Fragmentation of A-549 Cells

When cytochrome $c$ is released from the mitochondrial intermembrane space, apoptosome formation is triggered, leading to the induction of caspase- 9 and caspase-3 activation [29]. In Figure 8, it can be seen that the percentage of cells in the control with high caspase- 3 intensity was $39.6 \pm 0.3 \%$. Treatment of A-549 cells with $200 \mu \mathrm{g} / \mathrm{mL}$ SCA, SCAS1, and SCA-S2 for $48 \mathrm{~h}$ led to an increase in the percentage of cells with high caspase-3 intensity to $63.1 \pm 0.5 \%, 48.8 \pm 0.9 \%$, and $59.5 \pm 0.4 \%$, respectively, thus providing evidence that activation of caspase- 3 was mediated by fucoidan. Activation of caspase- 3 was shown to be a vital component of apoptotic cascades and triggers fragmentation of DNA, resulting in late phase apoptosis $[30,31]$. Figure 9 demonstrates that the percentage of cells in the control with a high DNA break-associated fluorescent intensity was $10.3 \pm 1.8 \%$. Treatment of A- 549 cells with $200 \mu \mathrm{g} / \mathrm{mL}$ SCA, SCA-S1, and SCA-S2 for $48 \mathrm{~h}$ significantly enhanced the percentage of cells with high DNA break-associated fluorescent intensity by $15.6 \pm 1.2 \%, 25.0 \pm 1.7 \%$, and $20.1 \pm 1.1 \%(p<0.05)$, respectively, suggesting the occurrence of fucoidan-mediated DNA fragmentation. 

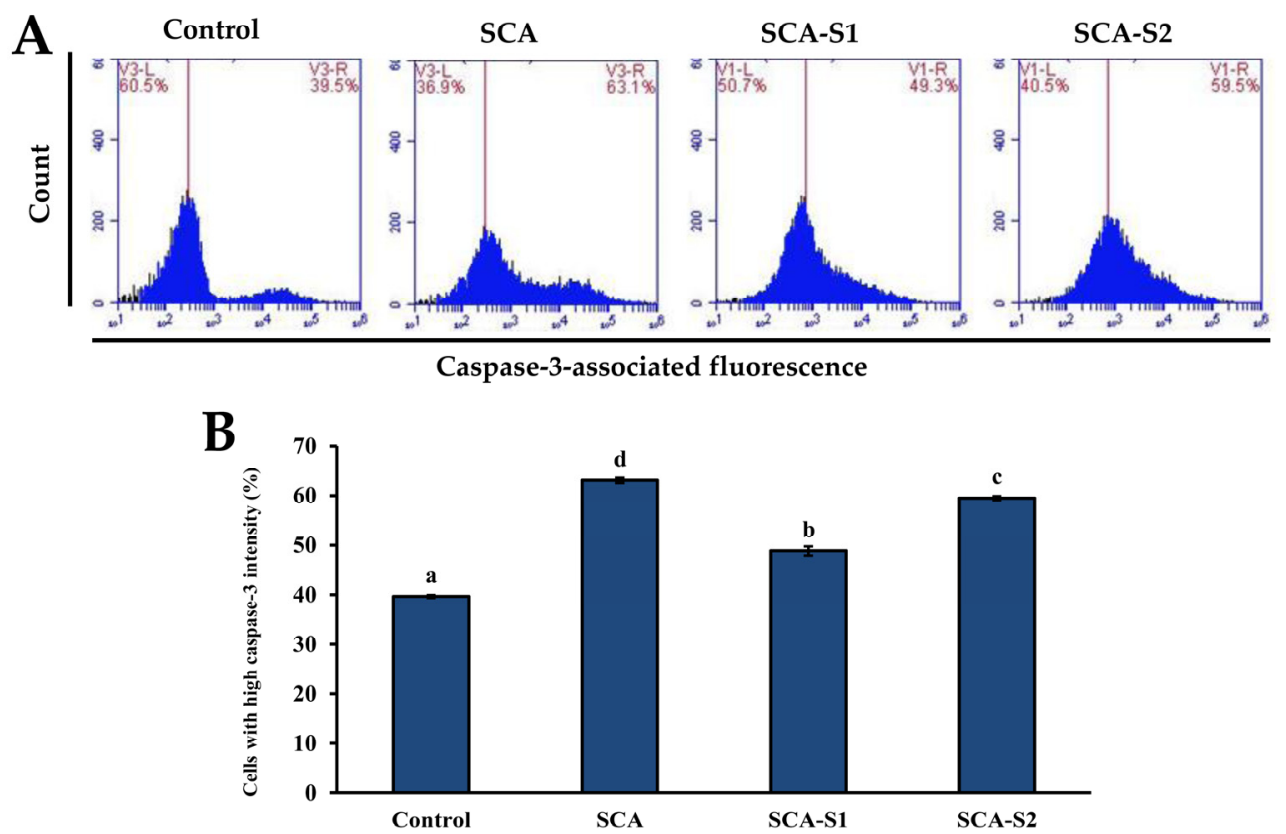

Figure 8. Effects of SCA, SCA-S1, and SCA-S2 treatments on the activation of caspase- 3 in A- 549 cells. A-549 cells were treated with and without $200 \mu \mathrm{g} / \mathrm{mL}$ SCA, SCA-S1, and SCA-S2 for $48 \mathrm{~h}$, and the level of immunolabeled caspase-3 was determined by flow cytometry. (A) Histograms; (B) summary bar graph of three cell cytometric analyses showing the percentages of cells with high caspase- 3 intensity according to treatments. Results are shown as mean \pm SD of three separate experiments. Differences exist between columns labeled with different letters at the level of 0.05 .

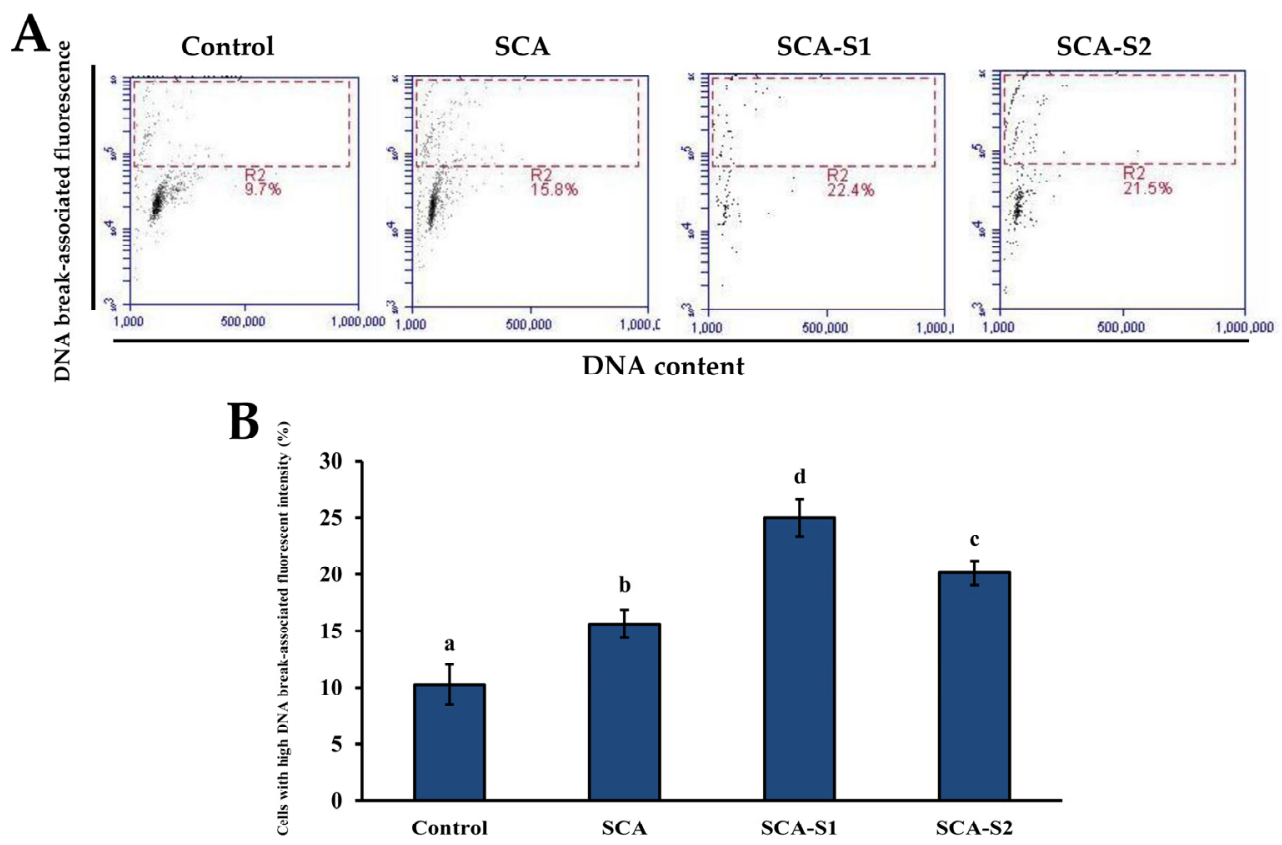

Figure 9. Effects of SCA, SCA-S1, and SCA-S2 treatments on the extent of DNA fragmentation in A-549 cells. A- 549 cells were treated with and without $200 \mu \mathrm{g} / \mathrm{mL}$ SCA, SCA-S1, and SCA-S2 for 48 $\mathrm{h}$, and the level of immunolabeled BrdU was determined by flow cytometry. (A) Histograms; (B) summary bar graph of three cell cytometric analyses showing the percentages of cells with high DNA break-associated fluorescent intensity according to treatments. Results are shown as mean \pm SD of three separate experiments. Differences exist between columns labeled with different letters at the level of 0.05 . 


\subsection{Effects of SCA, SCA-S1, and SCA-S2 on the Induction of Apoptosis in A-549 Cells}

Loss of plasma membrane asymmetry occurs early in apoptosis, leading to exposure of phosphatidylserine (PS) residues at the outer plasma membrane [32]. The specific binding of Annexin V to PS means that loss of plasma membrane integrity can be used in the detection of apoptosis [32]. The Annexin V-FITC and PI double-staining method is also capable of providing information related to necrotic cells as well as early- and late-stage apoptosis. Figure 10 shows that, in the control, the percentage of live cells was $68.0 \pm 0.8 \%$. Furthermore, treatment of A-549 cells with $200 \mu \mathrm{g} / \mathrm{mL}$ SCA, SCA-S1, and SCA-S2 for $48 \mathrm{~h}$ led to a decrease in the percentage of live cells to $27.2 \pm 1.3 \%, 2.38 \pm 0.83 \%$, and $2.93 \pm 0.40 \%$, respectively. Meanwhile, the percentage of late apoptotic cells in the control was $13.2 \pm 0.6 \%$. When A-549 cells were subjected to $200 \mu \mathrm{g} / \mathrm{mL}$ SCA, SCA-S1, and SCA-S2 for $48 \mathrm{~h}$, the percentage of late apoptotic cells rose to $45.2 \pm 1.0 \%, 75.9 \pm 0.7 \%$, and $80.5 \pm 1.1 \%$, respectively. The aforementioned findings clearly demonstrate that A-549 cellular death (primary late apoptosis) was induced by SCA, SCA-S1, and SCA-S2.
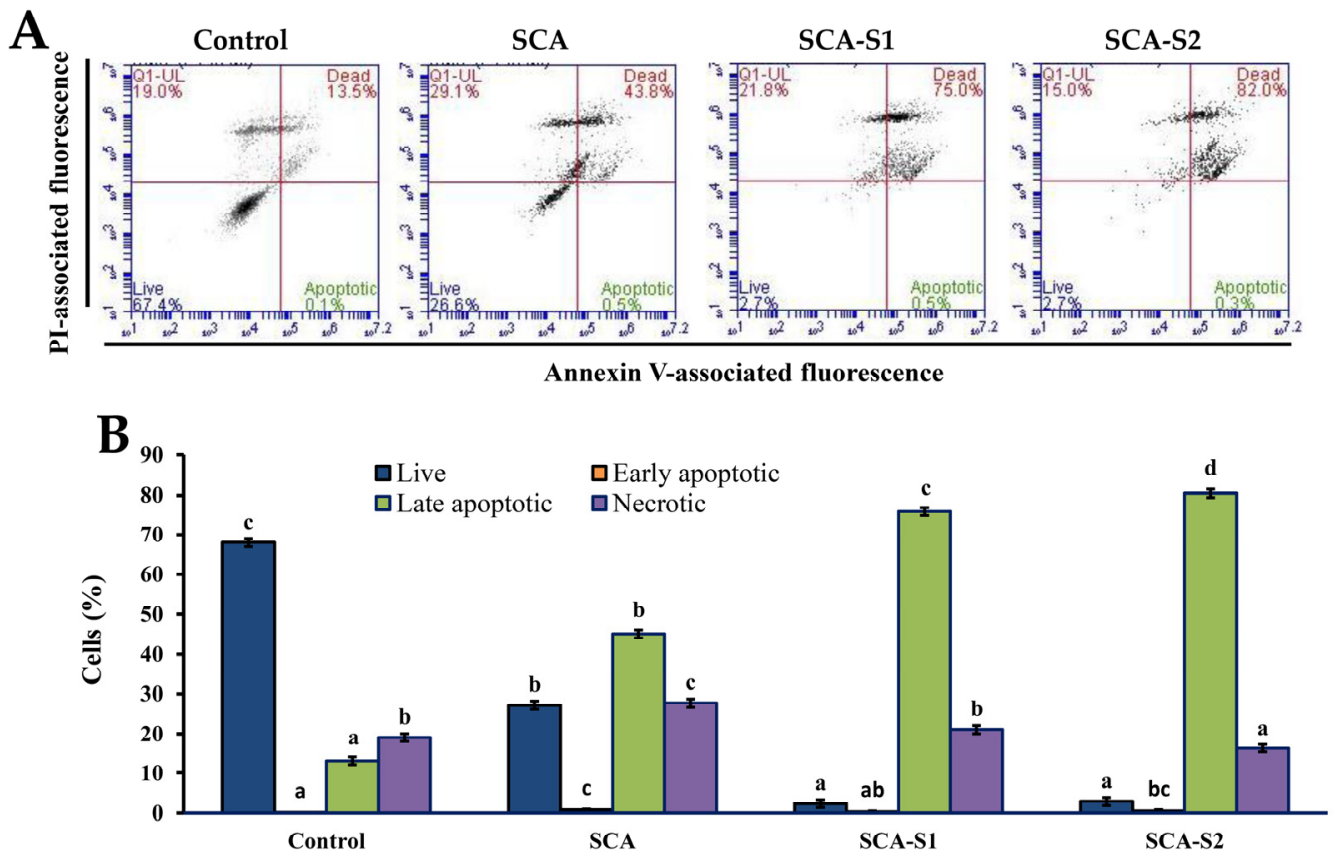

Figure 10. Effects of SCA, SCA-S1, and SCA-S2 treatments on the induction of apoptosis in A-549 cells. A-549 cells were treated with and without $200 \mu \mathrm{g} / \mathrm{mL}$ SCA, SCA-S1, and SCA-S2 for $48 \mathrm{~h}$, and the Annexin V-FITC/PI-stained cells were determined by flow cytometry. (A) Histograms; (B) summary bar graph of three cell cytometric analyses showing the percentages of Annexin V-FITC/PIstained cells according to treatments. Results are shown as mean \pm SD of three separate experiments. Differences exist between columns labeled with different letters at the level of 0.05 .

\subsection{SCA, SCA-S1, and SCA-S2 Induced Dephosphorylation of Akt, mTOR, and S6 in A-549 Cells}

Figure 11 depicts the percentage of cells in the control with high p-Akt intensity: $91.0 \pm 0.2 \%$. When A-549 cells were exposed to $200 \mu \mathrm{g} / \mathrm{mL} \mathrm{SCA}$, SCA-S1, and SCA-S2 for $48 \mathrm{~h}$, the percentage of cells with high p-Akt intensity fell to $88.6 \pm 1.9 \%, 65.3 \pm 3.0 \%$, and $67.6 \pm 3.5 \%$, respectively. Moreover, the percentage of cells with high Akt1 intensity in the control was $95.2 \pm 0.3 \%$. When A-549 cells were subjected to $200 \mu \mathrm{g} / \mathrm{mL}$ SCA, SCA-S1, and SCA-S2 for $48 \mathrm{~h}$, the percentage of cells with high Akt1 intensity was $94.1 \pm 1.0 \%$, $85.4 \pm 1.2 \%$, and $86.7 \pm 0.1 \%$, respectively. The percentage of cells with high p-mTOR intensity in the control was $81.0 \pm 0.4 \%$. Following the treatment of A-549 cells with 200 $\mu \mathrm{g} / \mathrm{mL}$ SCA, SCA-S1, and SCA-S2 for $48 \mathrm{~h}$, the percentage of cells with high p-mTOR intensity was reduced to $79.3 \pm 0.4 \%, 66.0 \pm 0.8 \%$, and $66.1 \pm 0.8 \%$, respectively. In the control, the percentage of cells with high p-S6 intensity was $88.2 \pm 0.7 \%$. The percentage 
of cells with high p-S6 intensity dropped to $69.2 \pm 0.9 \%, 50.3 \pm 2.3 \%$, and $64.1 \pm 1.2 \%$, respectively, when A-549 cells had been treated with $200 \mu \mathrm{g} / \mathrm{mL}$ SCA, SCA-S1, and SCA-S2 for $48 \mathrm{~h}$. The data above provide clear evidence of fucoidan-mediated dephosphorylation of Akt, mTOR, and S6 in A-549 cells.

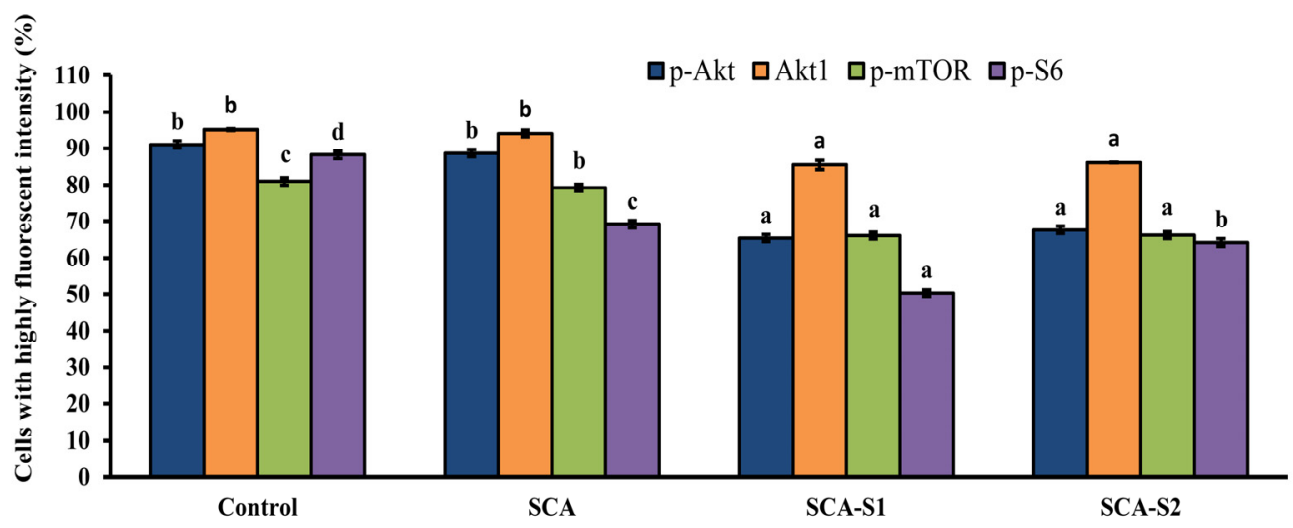

Figure 11. Effects of SCA, SCA-S1, and SCA-S2 treatments on the levels of p-Akt, Akt1, p-mTOR, and p-S6 in A-549 cells. A-549 cells were treated with and without $200 \mu \mathrm{g} / \mathrm{mL}$ SCA, SCA-S1, and SCA-S2 for $48 \mathrm{~h}$, and the cells with highly fluorescent intensity were determined by flow cytometry. The bar graph summary of three cell cytometric analyses shows the percentages of cells with highly fluorescent intensity according to treatments. Results are shown as mean $\pm \mathrm{SD}$ of three separate experiments. Differences exist between columns labeled with different letters at the level of 0.05 .

\section{Discussion}

A number of studies in the literature have indicated that oversulfated fucoidans exhibit greater anti-angiogenic activity compared to native fucoidans, and therefore by mitigating angiogenesis they can inhibit the growth of tumor cell growth more efficiently [6]. The wide range of anticancer activity seen among the various oversulfated fucoidan derivatives can probably be explained by differences in sulfate content [7]. The present study is an extension of our previous work on a native fucoidan (SC, extracted from Sargassum aquifolium) and three fucoidan hydrolysates, which we developed, termed SCA (degradation of SC by ascorbic acid), $\mathrm{SCH}$ (degradation of SC by hydrogen peroxide), and SCAH (degradation of SC by ascorbic acid + hydrogen peroxide). Our analyses determined that SCA was a suitable candidate for further development as an adjuvant therapy for lung cancer [8]. In the current study, we oversulfated SCA and developed two oversulfated fucoidans termed SCA-S1 and SCA-S2. The sulfate contents of SCA, SCA-S1, and SCA-S2 were $13.67 \pm 2.19 \%, 34.67 \pm 3.73 \%$, and $60.63 \pm 3.69 \%$, respectively (Table 1 ). In a study by Cho et al. [7], the addition of sulfate groups increased the sulfate content of the low molecular weight fucoidan $\left(\mathrm{F}_{5-30 \mathrm{~K}}\right.$ fraction) up to $56.8 \%$. The sulfate content of oversulfated $\mathrm{F}_{5-30 \mathrm{~K}}$ fraction was similar to that of SCA-S2, indicating that oversulfation of fucoidan is capable of yielding a sulfate content reaching as high as $60 \%$ (approx.). A summary of the chemical properties of SCA, SCA-S1, and SCA-S2 is presented in Table 1. Increases in sulfate content may result in a proportional decrease in the fucose content of fucoidan, suggesting that oversulfation may modify the fundamental structure of fucoidan. The FTIR spectra for SCA, SCA-S1, and SCA-S2 (Figure 1) depict broader peak areas at 1243 (the asymmetric stretching of $\mathrm{S}=\mathrm{O}), 840$ ( $\mathrm{C}-\mathrm{O}-\mathrm{S}$ bending vibration of sulfate substituents at the axial $\mathrm{C}-4$ position), and $620 / 580$ (the symmetric and anti-symmetric $\mathrm{O}=\mathrm{S}=\mathrm{O}$ deformations) $\mathrm{cm}^{-1}$ in SCA-S1 and SCA-S2, which are indicative of higher sulfate contents in SCA-S1 and SCA-S2. Moreover, Partankar et al. [33] reported that the sulfate peaks at around 820 and $840 \mathrm{~cm}^{-1}$ correspond to the equatorial C-2 and axial C-4 positions, respectively. In Figure 1, SCA showed a strong peak at around $840 \mathrm{~cm}^{-1}$, which indicates that the sulfates had largely been substituted at the C-4 position. In contrast, the oversulfated SCA-S1 and SCA-S2 both showed a pronounced peak at $840 \mathrm{~cm}^{-1}$ with a shoulder at $820 \mathrm{~cm}^{-1}$ (Figure 1), 
providing evidence of a 2,4 disubstitution of the sulfate groups. These findings are in line with previously reported studies [7], showing that sulfation resulted in the emergence of a shoulder at $820 \mathrm{~cm}^{-1}$ alongside the main peak at $840 \mathrm{~cm}^{-1}$ in the IR spectra, indicative of 2,4 disulfation. NMR spectra can be used to further evaluate the structural characteristics of oversulfated fucoidans. After oversulfation, the ${ }^{1} \mathrm{H}-\mathrm{NMR}$ and ${ }^{13} \mathrm{C}-\mathrm{NMR}$ spectra of SCA, SCA-S1, and SCA-S2 (Figure 2) were found to be different. Nonetheless, the characteristic peaks of fucoidan were also detected in SCA, SCA-S1, and SCA-S2. Sulfur trioxide $N, N-$ dimethylformamide complex ( $\mathrm{SO}_{3}$-DMF) (sulfating agents) in formamide (FA) solution was used to sulfate SCA-S1 and SCA-S2. Of note, the specific ${ }^{1} \mathrm{H}-\mathrm{NMR}$ and ${ }^{13} \mathrm{C}-\mathrm{NMR}$ signals representing DMF were detected in SCA-S1 and SCA-S2 (Figure 2), demonstrating the presence of sulfate groups in the fucoidan backbones.

In a previous study, we showed that the native fucoidan (SC) and fucoidan hydrolysates (SCA, SCH, and SCAH) lowered the ratios of live A-549 cells, and SCA, SCH, and SCAH conferred stronger cytotoxic effects on A-549 cells compared with SC [8]. However, all of the tested fucoidans (SC, SCA, SCH, and SCAH) showed less potent cytotoxic effects against normal BEAS-2B cells compared with that of A-549 cells [8]. Although there are a number of available human lung cancer cell lines that can be used to establish a tumor model, such as A-549, H-460, H-1299, H-1650, H-358, and HCC-827 [34], A-549 cells are adenocarcinomic human alveolar basal epithelial cells, which are widely used in models for the study of lung cancer and the development of drug therapies against it $[8,35]$. Moreover, A-549 cells are easy to maintain and grow faster compared with other lung cancer cells. Thus, A-549 cells were utilized in the present study to evaluate the anticancer effect of fucoidan extracts. In the current study, the most potent cytotoxic effects on A-549 cells were observed in SCA-S1 among the tested fucoidans (Figure $3 \mathrm{~A}$ ). The analyses of the cytotoxicities of SCA-S1 to A-549 cells and BEAS-2B cells at the concentration of $500 \mu \mathrm{g} / \mathrm{mL}$ revealed a survival rate of $19.3 \pm 1.0 \%$ in A-549 cells, but in BEAS-2B cells the survival rate was $55.5 \pm 1.0 \%$, showing that SCA-S1 had a toxic effect on normal cells that was 2.9-fold $(55.5 / 19.3=2.9)$ lower (Figure 3). Likewise, SCA-S2 was shown to have an approximately 3.0-fold $(72.4 / 24.2=3.0$ ) lower toxic effect on normal cells (Figure 3). In a study by Cho et al. [7], it was found that fucoidan $\left(\mathrm{F}_{>30 \mathrm{~K}}\right.$ fraction, sulfate content $=$ $41.2 \%$ ) exhibited $50 \%$ anticancer activity against AGS, a human stomach cancer cell line, at a concentration exceeding $800 \mu \mathrm{g} / \mathrm{mL}$. SCA-S1 possessed a sulfate content of $34.7 \%$, which was similar to that in the $\mathrm{F}_{>30 \mathrm{~K}}$ fraction, but it showed a $50 \%$ anticancer activity against A-549 cells at a concentration of $74.4 \mu \mathrm{g} / \mathrm{mL}$. While the cancer cell lines examined in the two aforementioned studies were different, the results still show that SCA-S1 confers a strongly potent effect against cancer cells.

Cell cycle analysis can be employed to assess the growth inhibitory effects of SCA, SCA-S1, and SCA-S2 on A-549 cells. Flow cytometry is a rapid technique that can be used to identify compounds capable of selective or preferential eradication of cancer cells by altering regulation of the cell cycle and/or inducing apoptosis. Treatment of cells with an apoptosis-inducing agent can lead to DNA fragmentation, which can also be analyzed by flow cytometry [24]. Small fragments of DNA can be eluted by washing with PBS. Any cells that have lost DNA will not be stained as obviously using PI stain and will appear to the left of the $G_{1}$ peak (the so-called sub- $G_{1}$ peak). Figure 4 shows that SCA-S2 had the highest percentage of cells in the sub- $G_{1}$ phase, followed by SCA-S1 and SCA. In Table 1, SCA-S2 had the greatest amount of sulfate, followed by SCA-S1 and SCA. Hence, increases in the sulfate content of fucoidan may promote the induction of sub- $G_{1}$ cell cycle arrest in a proportional manner.

MMP plays a vital role in cellular energy production (ATP) and in maintaining homeostasis within the cell [36]. MMP disruption is indicative of mitochondria dysfunction in the transduction of an apoptotic signal [37]. In Figure 5, SCA-S2 exerted the strongest effect in terms of induction of mitochondrial dysfunction in A-549 cells, followed by SCA-S1 and SCA. This trend was correlated with sulfate contents (Table 1). Bcl-2, an anti-apoptotic protein, has been postulated to block MMP depolarization, which in turn 
mitigates the activation of downstream apoptotic molecules, such as cytochrome $c$, AIF, and Smac/Diablo [26]. Moreover, suppression of Bcl-2 expression leads to cellular apoptosis. Figure 6 shows that all of the fucoidans were capable of suppressing the expression of Bcl-2, compared with the control. Release of cytochrome $c$ from the mitochondria is a nearly apoptotic event in the mitochondria-dependent apoptotic pathway [38,39]. According to Figure 7, SCA-S2 showed the greatest cytochrome $c$ release in A-549 cells, followed by SCA-S1 and SCA. This trend was in proportion to the sulfate contents of the fucoidans (Table 1). Taken together, these results indicate that induction of apoptosis by SCA, SCA-S1, and SCA-S2 was largely via a mitochondria-dependent apoptotic pathway. The sulfate content of fucoidan appears to play a key role in apoptotic cell death. The intrinsic pathway (mitochondria pathway) comprises a serial process involving loss of MMP, release of cytochrome $c$ into the cytoplasm, formation of an apoptosome complex, culminating in the activation of caspase-3 [40,41]. Furthermore, the activation of caspase-3 plays a pivotal role in DNA fragmentation, which occurs in late phase apoptosis [31]. All of the fucoidans promoted the activation of caspase-3, as compared to the control, as shown in Figure 8. In Figure 9, the results show that the degree of DNA fragmentation in A-549 cells was enhanced following treatment with SCA, SCA-S1, and SCA-S2. In short, the oversulfated fucoidans exhibited greater DNA fragmentation compared with SCA and the control. Moreover, Annexin V-FITC/PI double staining revealed these fucoidans were likely responsible for A-549 cell death (largely involving late apoptosis), and compared with SCA and the control, oversulfated fucoidans had greater numbers of late apoptotic cells (Figure 10).

Activation of the Akt/mTOR/S6 signaling is common in a wide range of cancers [42,43]. It has been shown that commercialized fucoidan extract from Fucus vesiculosus suppressed p-Akt and p-mTOR in A-549 cells in a dose- and time-dependent manner [44]. In the current investigation, we found that SCA, SCA-S1, and SCA-S2 suppressed levels of p$\mathrm{Akt}, \mathrm{p}-\mathrm{mTOR}$, and p-S6 in comparison with the untreated control. Moreover, the results indicated that SCA-S1 and SCA-S2 showed greater effectiveness with respect to reducing expressions of p-Akt, p-mTOR, and p-S6 compared with SCA. These results provide clear evidence that the oversulfated fucoidan enhances the anticancer activity (particularly against lung cancer) and the underlying mechanism involves the Akt/mTOR/S6 pathway. These encouraging findings could be useful in the future development of fucoidans with extensive sulfate substitution with a view to boosting their anticancer properties. While the precise mechanism has yet to be fully elucidated, it is reasonable to postulate that the elevated negative charge induced by oversulfation enhances the interaction with particular proteins, including plasmatic proteins, adhesion proteins, and growth factors that play a role in cell proliferation, thereby facilitating cell growth suppression $[7,45]$. Further research is required to gain a complete understanding of the underlying mechanism of action of oversulfated fucoidans using other lung cancer cell lines, and to conduct in vivo models to investigate the upstream and downstream targeting molecules of signaling pathways in lung cancer.

\section{Materials and Methods}

\subsection{Materials}

Samples of Sargassum aquifolium were collected from Kenting (Pingtung, Taiwan). After washing and drying, samples were sealed in aluminum foil bags and kept at $4{ }^{\circ} \mathrm{C}$ until use. L-fucose, D-galactose, D-glucuronic acid, D-galacturonic acid, D-xylose, Dmannose, dimethyl sulfoxide (DMSO), potassium bromide (KBr), 2,2,2-Trifluoroacetic acid (TFA), and 3-(4,5-dimethylthiazol-2-yl)-2,5-diphenyltetrazolium bromide (MTT) were obtained from Sigma-Aldrich (St. Louis, MO, USA). Ham's F12K medium, DMEM medium, trypsin/EDTA, fetal bovine serum (FBS), penicillin, and streptomycin were purchased from Gibco Laboratories (Grand Island, NY, USA). TMRE was obtained from Molecular Probes, Invitrogen Corp. (Carlsbad, CA, USA). Unless otherwise stated, other reagents were purchased from Sigma-Aldrich (St. Louis, MO, USA). 


\subsection{Sulfation of Fucoidan}

SCA was produced in accordance with the methods described in our previous studies [8]. Sulfation of SCA was performed according to the method described by Wang et al. [22]. The sulfation reagent, $\mathrm{SO}_{3}-\mathrm{DMF}$, was obtained by dropping $20 \mathrm{~mL}$ of chlorosulfonic acid into $100 \mathrm{~mL}$ of $\mathrm{N}, \mathrm{N}$-dimethylformamide under cooling in an ice-water bath. Dry SCA $(0.1 \mathrm{~g})$ was added to $10 \mathrm{~mL}$ formamide (FA), and the mixture was stirred at RT for 30 min in order to disperse it into the solvent. Then $10 \mathrm{~mL} \mathrm{SO}_{3}$-DMF reagent (for SCA-S1) or $20 \mathrm{~mL} \mathrm{SO} 3$-DMF reagent (for SCA-S2) was added. After reaction at RT for $4 \mathrm{~h}$, the solution was neutralized to $\mathrm{pH}=7.0$ with $1 \mathrm{~mol} / \mathrm{L} \mathrm{NaOH}$ solution and dialyzed against distilled water for $24 \mathrm{~h}$ using $1000 \mathrm{Da}$ MW cutoff dialysis membranes. The remnant was concentrated and lyophilized to obtain SCA-S1 and SCA-S2.

\subsection{Analytical Methods}

The fucose content was estimated using the protocol described by Huang et al. [46] and L-fucose was used as the standard. For the determination of the sulfate content, the sample was firstly hydrolyzed with $1 \mathrm{~N} \mathrm{HCl}$ solution for $5 \mathrm{~h}$ at $105^{\circ} \mathrm{C}$. The hydrolysate was quantified to determine the percentage of sulfate composition using Dionex ICS-1500 Ion Chromatography with IonPac AS9-HC column at a flow rate of $1 \mathrm{~mL} / \mathrm{min}$ at $30{ }^{\circ} \mathrm{C}$ with conductometric detection. The eluent was $9 \mathrm{mM} \mathrm{Na}_{2} \mathrm{CO}_{3}$, and $\mathrm{K}_{2} \mathrm{SO}_{4}$ was utilized as standard. Total sugar content was assayed using a phenol-sulfuric acid method using L-fucose as the standard.

\subsection{Monosaccharide Composition Analysis}

For the determination of monosaccharide composition, the sample was first hydrolyzed with $2 \mathrm{M}$ trifluoroacetic acid (TFA) for $4 \mathrm{~h}$ at $110{ }^{\circ} \mathrm{C}$. After removing the residual acid, the standard sugars and sample were pre-column derivatized with 1-phenyl-3-methyl5-pyrazolone (PMP) for $100 \mathrm{~min}$ at $70{ }^{\circ} \mathrm{C}$. The resulting solutions were extracted with chloroform three times. Then the PMP derivatives were eluted with a mixture of $0.1 \mathrm{M}$ phosphate buffer $(\mathrm{pH}$ 6.7) and acetonitrile in a ratio of 83:17 $(v / v, \%)$ at a flow rate of 1 $\mathrm{mL} / \mathrm{min}$ on a reversed-phase Inspire ${ }^{\mathrm{TM}} \mathrm{C} 18(250 \times 4.6 \mathrm{~mm}, 5 \mu \mathrm{m})$ column with detection at $245 \mathrm{~nm}$. L-fucose, D-galactose, D-glucuronic acid, D-galacturonic acid, D-xylose, and D-mannose were used as standards.

\subsection{FTIR Spectroscopy}

The FTIR spectra were analyzed according to a protocol described in Huang et al. [47]. In brief, the sample was ground evenly with $\operatorname{KBr}(1: 50, w / w, \%)$ until particles measured less than $2.5 \mu \mathrm{m}$ in size. The transparent $\mathrm{KBr}$ pellets were prepared at $500 \mathrm{~kg} / \mathrm{cm}^{2}$ under vacuum conditions. The FTIR spectra were obtained using an FT-730 spectrometer (Horiba, Kyoto, Japan). The signals were automatically collected using 60 scans over the range of $4000-400 \mathrm{~cm}^{-1}$ at a resolution of $16 \mathrm{~cm}^{-1}$ and were compared to a background spectrum collected from the $\mathrm{KBr}$ alone.

\subsection{NMR Spectroscopy}

The fucoidan sample was dissolved with $99.9 \% \mathrm{D}_{2} \mathrm{O}$ in an NMR tube and the NMR spectra were recorded using a Varian VNMRS-700 NMR spectrometer (Varian, Lexington, MA, USA).

\subsection{Cell Culture}

A-549 (human lung carcinoma, BCRC 60074, cultured in complete Ham's F12K medium) and BEAS-2B (human bronchial epithelial cells, ATCC CRL-9609, cultured in complete DMEM medium) were obtained from the BCRC (Bioresource Collection and Research Center, Hsinchu, Taiwan) and the ATCC (American Type Culture Collection, Manassas, VA, USA), respectively. All cells were cultured in a $37^{\circ} \mathrm{C}$ humidified $5 \% \mathrm{CO}_{2}$ atmosphere, and the medium was changed every two to three days. 


\subsection{Evaluation of Cytotoxic Activity}

The cytotoxic activity of the fucoidan derivatives was measured using the MTT assay. Cells were cultured in medium at $37{ }^{\circ} \mathrm{C}$ in a humidified atmosphere with $5 \% \mathrm{CO}_{2}$ for $24 \mathrm{~h}$. The stock solution of fucoidan extract was prepared by dissolving it in phosphate-buffered saline (PBS) to a concentration of $20 \mathrm{mg} / \mathrm{mL}$. The medium was then removed and the cells were treated with different concentrations of fucoidan extracts by diluting the stock solution with serum-free medium. After $48 \mathrm{~h}$ treatment, cells were washed with PBS once, and MTT reagent $(0.1 \mathrm{mg} / \mathrm{mL})$ was added. After a $4 \mathrm{~h}$ incubation, isopropanol was added and thoroughly mixed by pipetting to dissolve the formazan. The resultant solution was measured by absorption at $560 \mathrm{~nm}$ using a spectrophotometer. The cell viability was expressed as a percentage of MTT reduction.

\subsection{Flow Cytometry-Based Analyses}

In all flow cytometry-based analyses, cells $\left(4 \times 10^{4}\right.$ cells $\left./ \mathrm{mL}\right)$ were incubated without (as a non-treated control) and with $200 \mu \mathrm{g} / \mathrm{mL}$ tested samples for $48 \mathrm{~h}$, and then cells were trypsinized and rinsed with PBS to obtain cell samples. Then, each flow cytometry-based analysis was performed according to the following procedures.

The cell cycle analysis was performed according to the method described previously [48]. Briefly, A-549 cells were collected, washed twice with PBS, resuspended in $70 \%(v / v)$ ethanol, and stored at $4{ }^{\circ} \mathrm{C}$ for at least $2 \mathrm{~h}$. The cells were then washed with staining buffer twice, and stained with $25 \mu \mathrm{g} / \mathrm{mL}$ RNase A. After staining with RNase A for $15 \mathrm{~min}$, the cells were stained with $50 \mu \mathrm{g} / \mathrm{mL}$ PI solution, and flow cytometry-based analysis was performed.

For the MMP analysis, the assay was performed using the method of Yang et al. [49]. Briefly, single cell suspensions were washed twice with PBS and incubated, in the dark, for 20 min at $37^{\circ} \mathrm{C}$ with TMRE (100 nM). After labeling, cells were washed and resuspended for flow-cytometric measurement in staining solution.

The Bcl-2 assay was done according to the method described by Yang et al. [49]. In brief, single-cell suspensions were fixed using fixation buffer at $37^{\circ} \mathrm{C}$ for $20 \mathrm{~min}$. The cells were subsequently permeabilized using permeabilization buffer, and incubated, in the dark, for $1 \mathrm{~h}$ at RT with FITC (fluorescein isothiocyanate)-labeled anti-Bcl-2 antibody (1:25, $v / v$ ). After labeling, cells were washed and resuspended for flow-cytometric measurement in staining solution.

The analysis of cytochrome $c$ release was conducted according to the protocol described by Huang et al. [12]. Briefly, single-cell suspensions were fixed using fixation buffer at $37^{\circ} \mathrm{C}$ for $20 \mathrm{~min}$. The cells were subsequently permeabilized using permeabilization buffer and incubated in the dark for $1 \mathrm{~h}$ at RT with FITC-labeled anti-cytochrome $c$ antibody $(1: 10, v / v)$. After labeling, cells were washed and resuspended for flow-cytometric measurement in staining solution.

For activated caspase-3 analysis, the method of Huang et al. [12] was employed. Briefly, single-cell suspensions were incubated, in the dark, for $1 \mathrm{~h}$ at $37^{\circ} \mathrm{C}$ with FITC-DEVDFMK solution. After labeling, cells were washed and resuspended for flow-cytometric measurement in staining solution.

For DNA fragmentation analysis, the procedure was conducted using the method described by Shiao et al. [50]. Briefly, A-549 cells were harvested and fixed with $4 \%$ paraformaldehyde, washed, and then incubated with $70 \%$ ice-cold ethanol at $-20{ }^{\circ} \mathrm{C}$ overnight. Cells were washed with wash buffer, followed by the addition of BrdU, and then incubated with FITC-conjugated anti-BrdU antibody at RT for 30 min in the dark. After staining, the cells were resuspended in staining buffer for flow analysis.

The Annexin V-FITC/PI staining analysis was performed with an Annexin V-FITC apoptosis detection kit following the protocol described by Yang et al. [49]. Briefly, singlecell suspensions were incubated for $15 \mathrm{~min}$ at RT in the dark with Annexin V-FITC (1:20, $v / v)$ and PI $(1: 20, v / v)$. After labeling, cells were washed and resuspended for flowcytometric measurement in staining solution. 
For phosphorylated Akt, mTOR, and S6 analyses, as well as Akt1, were done using the techniques described by Huang et al. [51]. In brief, single-cell suspensions were fixed using fixation buffer at $37^{\circ} \mathrm{C}$ for $1 \mathrm{~h}$. The cells were then incubated at RT for $1 \mathrm{~h}$ in the dark with APC (allophycocyanin)-conjugated anti-Akt1 antibody (1:50, $v / v)$, FITCconjugated anti-phospho-Akt (Ser473) antibody $(1: 20, v / v)$, PE (phycoerythrin)-conjugated anti-phospho-mTOR (Ser2448) antibody (1:20, $v / v)$, or PE-conjugated anti-phospho-S6 (Ser235, Ser236) antibody (1:20, $v / v)$. After labeling, cells were washed and resuspended for flow-cytometric measurement in staining solution. All of the abovementioned flow cytometric analyses were performed with a BD Accuri C6 flow cytometer (San Jose, CA, USA). All of the flow data were analyzed using BD Accuri C6 software.

\subsection{Statistical Analysis}

All data are expressed as mean $\pm \mathrm{SD}(n=3)$. Comparisons between different groups were performed by ANOVA followed by Duncan's multiple range test. A $p$-value less than 0.05 was considered statistically significant.

\section{Conclusions}

In this investigation, we successfully produced three fucoidans (SCA, SCA-S1, and SCA-S2) from Sargassum aquifolium, which contained different levels of sulfate content. Comparisons of SCA, SCA-S1, and SCA-S2 revealed differences in chemical compositions and structural features as a result of oversulfation treatment. The mitochondrion-dependent pathway was predominant in SCA-, SCA-S1-, and SCA-S2-induced apoptosis of A-549 cells as evidenced by the analyses of mitochondrial membrane potential (MMP), cytochrome $c$ release, Bcl-2 expression, activation of caspase-3, and DNA fragmentation. Moreover, we demonstrated that oversulfation of fucoidan enhanced its activity against lung cancer cells and determined that the underlying mechanism likely involves the Akt/mTOR/S6 pathway. Our results indicate that oversulfated fucoidans hold considerable promise for further development for application as an adjuvant therapy in the treatment of cancer, especially lung cancer.

Author Contributions: Conceptualization, T.-C.W. and H.-H.H.; methodology, Y.-H.T.; software, H.-H.H.; validation, R.-H.H., Y.-H.H., and C.-Y.H.; formal analysis, H.-H.H., R.-H.H., and Y.-H.H.; investigation, Y.-H.T., C.-H.K., and Y.-H.H.; resources, C.-H.K., H.-H.H.; data curation, R.-H.H. and T.-C.W.; writing—original draft preparation, H.-H.H., Y.-H.H., and C.-H.K.; writing-review and editing, C.-H.K. and C.-Y.H.; supervision, Y.-H.H.; project administration, C.-Y.H.; funding acquisition, H.-H.H., Y.-H.H., and C.-Y.H. All authors have read and agreed to the published version of the manuscript.

Funding: This research was funded by a grant provided by Kaohsiung Medical University Hospital (KMUH109-9R19) to Hui-Hua Hsiao. This work was also supported by the Ministry of Science and Technology, Taiwan (grant number MOST 109-2221-E-992-052) and National Kaohsiung University of Science and Technology, Taiwan (grant number 110G07), which were awarded to Chun-Yung Huang. The authors thank the Ministry of Education, Taiwan, for supporting this study (grant number MOE-RSC-108RSN0005), awarded to Yong-Han Hong.

Institutional Review Board Statement: Not applicable.

Informed Consent Statement: Not applicable.

Data Availability Statement: Data is contained within the article.

Conflicts of Interest: The authors declare no conflict of interest.

\section{References}

1. Frión-Herrera, Y.; Díaz-García, A.; Ruiz-Fuentes, J.; Rodríguez-Sánchez, H.; Sforcin, J.M. Brazilian green propolis induced apoptosis in human lung cancer A549 cells through mitochondrial-mediated pathway. J. Pharm. Pharmacol. 2015, 67, 1448-1456. [CrossRef]

2. Islami, F.; Torre, L.A.; Jemal, A. Global trends of lung cancer mortality and smoking prevalence. Transl. Lung Cancer Res. 2015, 4, 327-338. 
3. Ministry of Health and Welfare. Taiwan, Statistics of Causes of Death. Available online: https://dep.mohw.gov.tw/DOS/lp-4927 -113.html (accessed on 15 March 2021).

4. Wang, J.; Zhang, Q.; Li, S.; Chen, Z.; Tan, J.; Yao, J.; Duan, D. Low molecular weight fucoidan alleviates diabetic nephropathy by binding fibronectin and inhibiting ECM-receptor interaction in human renal mesangial cells. Int. J. Biol. Macromol. 2020, 150, 304-314. [CrossRef]

5. Soeda, S.; Sakaguchi, S.; Shimeno, H.; Nagamatsu, A. Fibrinolytic and anticoagulant activities of highly sulfated fucoidan. Biochem. Pharmacol. 1992, 43, 1853-1858. [CrossRef]

6. Koyanagi, S.; Tanigawa, N.; Nakagawa, H.; Soeda, S.; Shimeno, H. Oversulfation of fucoidan enhances its anti-angiogenic and antitumor activities. Biochem. Pharmacol. 2003, 65, 173-179. [CrossRef]

7. Cho, M.L.; Lee, B.Y.; You, S.G. Relationship between oversulfation and conformation of low and high molecular weight fucoidans and evaluation of their in vitro anticancer activity. Molecules 2011, 16, 291-297. [CrossRef] [PubMed]

8. Wu, T.C.; Hong, Y.H.; Tsai, Y.H.; Hsieh, S.L.; Huang, R.H.; Kuo, C.H.; Huang, C.Y. Degradation of Sargassum crassifolium fucoidan by ascorbic acid and hydrogen peroxide, and compositional, structural, and in vitro anti-Lung cancer analyses of the degradation products. Mar. Drugs 2020, 18, 334. [CrossRef]

9. Movasaghi, Z.; Rehman, S.; Ur Rehman, D.I. Fourier transform infrared (FTIR) spectroscopy of biological tissues. Appl. Spectrosc. Rev. 2008, 43, 134-179. [CrossRef]

10. Shao, P.; Pei, Y.P.; Fang, Z.X.; Sun, P.L. Effects of partial desulfation on antioxidant and inhibition of DLD cancer cell of Ulva fasciata polysaccharide. Int. J. Biol. Macromol. 2014, 65, 307-313. [CrossRef] [PubMed]

11. Palanisamy, S.; Vinosha, M.; Marudhupandi, T.; Rajasekar, P.; Prabhu, N.M. Isolation of fucoidan from Sargassum polycystum brown algae: Structural characterization, in vitro antioxidant and anticancer activity. Int. J. Biol. Macromol. 2017, 102, 405-412. [CrossRef] [PubMed]

12. Huang, C.Y.; Kuo, C.H.; Chen, P.W. Compressional-puffing pretreatment enhances neuroprotective effects of fucoidans from the brown seaweed Sargassum hemiphyllum on 6-hydroxydopamine-induced apoptosis in SH-SY5Y cells. Molecules 2018, 23, 78. [CrossRef] [PubMed]

13. Synytsya, A.; Bleha, R.; Synytsya, A.; Pohl, R.; Hayashi, K.; Yoshinaga, K.; Nakano, T.; Hayashi, T. Mekabu fucoidan: Structural complexity and defensive effects against avian influenza A viruses. Carbohydr. Polym. 2014, 111, 633-644. [CrossRef] [PubMed]

14. Tako, M.; Nakada, T.; Hongou, F. Chemical characterization of fucoidan from commercially cultured Nemacystus decipiens (Itomozuku). Biosci. Biotechnol. Biochem. 1999, 63, 1813-1815. [CrossRef] [PubMed]

15. Immanuel, G.; Sivagnanavelmurugan, M.; Marudhupandi, T.; Radhakrishnan, S.; Palavesam, A. The effect of fucoidan from brown seaweed Sargassum wightii on WSSV resistance and immune activity in shrimp Penaeus monodon (Fab). Fish Shellfish Immunol. 2012, 32, 551-564. [CrossRef] [PubMed]

16. Jégou, C.; Kervarec, N.; Cérantola, S.; Bihannic, I.; Stiger-Pouvreau, V. NMR use to quantify phlorotannins: The case of Cystoseira tamariscifolia, a phloroglucinol-producing brown macroalga in Brittany (France). Talanta 2015, 135, 1-6. [CrossRef] [PubMed]

17. Ermakova, S.; Sokolova, R.; Kim, S.M.; Um, B.H.; Isakov, V.; Zvyagintseva, T. Fucoidans from brown seaweeds Sargassum hornery, Eclonia cava, Costaria costata: Structural characteristics and anticancer activity. Appl. Biochem. Biotechnol. 2011, 164, 841-850. [CrossRef] [PubMed]

18. Bilan, M.I.; Grachev, A.A.; Ustuzhanina, N.E.; Shashkov, A.S.; Nifantiev, N.E.; Usov, A.I. A highly regular fraction of a fucoidan from the brown seaweed Fucus distichus L. Carbohydr. Res. 2004, 339, 511-517. [CrossRef] [PubMed]

19. Kumar, T.V.; Lakshmanasenthil, S.; Geetharamani, D.; Marudhupandi, T.; Suja, G.; Suganya, P. Fucoidan-A $\alpha$-D-glucosidase inhibitor from Sargassum wightii with relevance to type 2 diabetes mellitus therapy. Int. J. Biol. Macromol. 2015, 72, $1044-1047$. [CrossRef] [PubMed]

20. Vishchuk, O.S.; Ermakova, S.P.; Zvyagintseva, T.N. Sulfated polysaccharides from brown seaweeds Saccharina japonica and Undaria pinnatifida: Isolation, structural characteristics, and antitumor activity. Carbohydr. Res. 2011, 346, 2769-2776. [CrossRef]

21. Imbs, T.I.; Ermakova, S.P.; Malyarenko, O.S.; Isakov, V.V.; Zvyagintseva, T.N. Structural elucidation of polysaccharide fractions from the brown alga Coccophora langsdorfii and in vitro investigation of their anticancer activity. Carbohydr. Polym. 2016, 135, 162-168. [CrossRef]

22. Wang, J.; Wang, F.; Zhang, Q.; Zhang, Z.; Shi, X.; Li, P. Synthesized different derivatives of low molecular fucoidan extracted from Laminaria japonica and their potential antioxidant activity in vitro. Int. J. Biol. Macromol. 2009, 44, 379-384. [CrossRef]

23. Chen, H.M.; Lee, M.J.; Kuo, C.Y.; Tsai, P.L.; Liu, J.Y.; Kao, S.H. Ocimum gratissimum aqueous extract induces apoptotic signalling in lung adenocarcinoma cell A549. Evid. Based Complement. Altern. Med. 2011, 2011, 739093. [CrossRef]

24. Ma, L.; Qin, C.; Wang, M.; Gan, D.; Cao, L.; Ye, H.; Zeng, X. Preparation, preliminary characterization and inhibitory effect on human colon cancer HT-29 cells of an acidic polysaccharide fraction from Stachys floridana Schuttl. ex Benth. Food Chem. Toxicol. 2013, 60, 269-276. [CrossRef]

25. Green, D.R.; Kroemer, G. The pathophysiology of mitochondrial cell death. Science 2004, 305, 626-629. [CrossRef]

26. Penninger, J.M.; Kroemer, G. Mitochondria, AIF and caspases-Rivaling for cell death execution. Nat. Cell Biol. 2003, 5, 97-99. [CrossRef] [PubMed]

27. Tissot, B.; Salpin, J.-Y.; Martinez, M.; Gaigeot, M.-P.; Daniel, R. Differentiation of the fucoidan sulfated L-fucose isomers constituents by CE-ESIMS and molecular modeling. Carbohydr. Res. 2006, 341, 598-609. [CrossRef] 
28. Wang, C.Y.; Wu, T.C.; Hsieh, S.L.; Tsai, Y.H.; Yeh, C.W.; Huang, C.Y. Antioxidant activity and growth inhibition of human colon cancer cells by crude and purified fucoidan preparations extracted from Sargassum cristaefolium. J. Food Drug Anal. 2015, 23, 766-777. [CrossRef] [PubMed]

29. Jiang, X.; Wang, X. Cytochrome-c-mediated apoptosis. Annu. Rev. Biochem. 2004, 73, 87-106. [CrossRef] [PubMed]

30. Enari, M.; Sakahira, H.; Yokoyama, H.; Okawa, K.; Iwamatsu, A.; Nagata, S. A caspase-activated DNase that degrades DNA during apoptosis, and its inhibitor ICAD. Nature 1998, 391, 43-50. [CrossRef]

31. Liu, X.S.; Li, P.; Widlak, P.; Zou, H.; Luo, X.; Garrard, W.T.; Wang, X.D. The 40-kDa subunit of DNA fragmentation factor induces DNA fragmentation and chromatin condensation during apoptosis. Proc. Natl. Acad. Sci. USA 1998, 95, 8461-8466. [CrossRef] [PubMed]

32. Van Engeland, M.; Nieland, L.J.; Ramaekers, F.C.; Schutte, B.; Reutelingsperger, C.P. Annexin V-affinity assay: A review on an apoptosis detection system based on phosphatidylserine exposure. Cytometry 1998, 31, 1-9. [CrossRef]

33. Patankar, M.S.; Oehninger, S.; Barnett, T.; Williams, R.L.; Clark, G.F. A revised structure for fucoidan may explain some of its biological activities. J. Biol. Chem. 1993, 268, 21770-21776. [CrossRef]

34. Wang, J.; Wang, L.; Ho, C.-T.; Zhang, K.; Liu, Q.; Zhao, H. Garcinol from Garcinia indica downregulates cancer stem-like cell biomarker ALDH1A1 in nonsmall cell lung cancer A549 cells through DDIT3 activation. J. Agric. Food Chem. 2017, 65, 3675-3683. [CrossRef] [PubMed]

35. Foster, K.A.; Oster, C.G.; Mayer, M.M.; Avery, M.L.; Audus, K.L. Characterization of the A549 cell line as a type II pulmonary epithelial cell model for drug metabolism. Exp. Cell Res. 1998, 243, 359-366. [CrossRef] [PubMed]

36. Tang, X.Q.; Feng, J.Q.; Chen, J.; Chen, P.X.; Zhi, J.L.; Cui, Y.; Guo, R.X.; Yu, H.M. Protection of oxidative preconditioning against apoptosis induced by $\mathrm{H}_{2} \mathrm{O}_{2}$ in PC12 cells: Mechanisms via MMP, ROS, and Bcl-2. Brain Res. 2005, 1057, 57-64. [CrossRef] [PubMed]

37. Weng, D.; Lu, Y.; Wei, Y.; Liu, Y.; Shen, P. The role of ROS in microcystin-LR-induced hepatocyte apoptosis and liver injury in mice. Toxicology 2007, 232, 15-23. [CrossRef]

38. Gogvadze, V.; Orrenius, S.; Zhivotovsky, B. Multiple pathways of cytochrome $c$ release from mitochondria in apoptosis. Biochim. Biophys. Acta Bioenergy 2006, 1757, 639-647. [CrossRef]

39. Campos, C.B.; Paim, B.A.; Cosso, R.G.; Castilho, R.F.; Rottenberg, H.; Vercesi, A.E. Method for monitoring of mitochondrial cytochrome $c$ release during cell death: Immunodetection of cytochrome $c$ by flow cytometry after selective permeabilization of the plasma membrane. Cytom. Part A J. Int. Soc. Anal. Cytol. 2006, 69, 515-523. [CrossRef] [PubMed]

40. Fox, R.; Aubert, M. Flow cytometric detection of activated caspase. In Apoptosis and Cancer: Methods and Protocols, 2008 ed.; Mor, G., Alvero, A.B., Eds.; Humana Press Inc.: Totowa, NJ, USA, 2008; pp. 47-56.

41. Robertson, J.D.; Orrenius, S.; Zhivotovsky, B. Nuclear events in apoptosis. J. Struct. Biol. 2000, 129, 346-358. [CrossRef]

42. Dienstmann, R.; Rodon, J.; Serra, V.; Tabernero, J. Picking the point of inhibition: A comparative review of PI3K/AKT/mTOR pathway inhibitors. Mol. Cancer Ther. 2014, 13, 1021-1031. [CrossRef]

43. Polivka, J., Jr.; Janku, F. Molecular targets for cancer therapy in the PI3K/AKT/mTOR pathway. Pharmacol. Ther. 2014, 142, 164-175. [CrossRef] [PubMed]

44. Lee, H.; Kim, J.-S.; Kim, E. Fucoidan from seaweed Fucus vesiculosus inhibits migration and invasion of human lung cancer cell via PI3K-Akt-mTOR pathways. PLoS ONE 2012, 7, e50624. [CrossRef] [PubMed]

45. Haroun-Bouhedja, F.; Ellouali, M.; Sinquin, C.; Boisson-Vidal, C. Relationship between sulfate groups and biological activities of fucans. Thromb. Res. 2000, 100, 453-459. [CrossRef]

46. Huang, C.Y.; Wu, S.J.; Yang, W.N.; Kuan, A.W.; Chen, C.Y. Antioxidant activities of crude extracts of fucoidan extracted from Sargassum glaucescens by a compressional-puffing-hydrothermal extraction process. Food Chem. 2016, 197, 1121-1129. [CrossRef]

47. Huang, C.Y.; Kuo, C.H.; Lee, C.H. Antibacterial and antioxidant capacities and attenuation of lipid accumulation in 3T3-L1 adipocytes by low-molecular-weight fucoidans prepared from compressional-puffing-pretreated Sargassum crassifolium. Mar. Drugs 2018, 16, 24. [CrossRef] [PubMed]

48. Wang, C.Y.; Wu, T.C.; Wu, C.H.; Tsai, Y.H.; Chung, S.M.; Hong, Y.H.; Huang, C.Y. Antioxidant, anti-inflammatory, and HEP G2 cell growth-inhibitory effects of aqueous-ethanol extracts obtained from non-puffed and compressional-puffed Sargassum crassifolium. J. Mar. Sci. Technol. 2020, 28, 200-210.

49. Yang, W.N.; Chen, P.W.; Huang, C.Y. Compositional characteristics and in vitro evaluations of antioxidant and neuroprotective properties of crude extracts of fucoidan prepared from compressional puffing-pretreated Sargassum crassifolium. Mar. Drugs 2017, 15, 183. [CrossRef] [PubMed]

50. Shiao, W.C.; Kuo, C.H.; Tsai, Y.H.; Hsieh, S.L.; Kuan, A.W.; Hong, Y.H.; Huang, C.Y. In vitro evaluation of anti-colon cancer potential of crude extracts of fucoidan obtained from Sargassum glaucescens pretreated by compressional-puffing. Appl. Sci. 2020, 10, 3058. [CrossRef]

51. Huang, C.Y.; Wu, T.C.; Hong, Y.H.; Hsieh, S.L.; Guo, H.R.; Huang, R.H. Enhancement of cell adhesion, cell growth, wound healing, and oxidative protection by gelatins extracted from extrusion-pretreated tilapia (Oreochromis sp.) fish scale. Molecules 2018, 23, 2406. [CrossRef] [PubMed] 